\title{
Palmeiras (Arecaceae) no Rio Grande do Sul, Brasil
}

\author{
Palms (Arecaceae) from Rio Grande do Sul, Brazil
}

Kelen Pureza Soares ${ }^{1,4}$, Solon Jonas Longhi ${ }^{1}$, Leopoldo Witeck Neto ${ }^{2}$ \& Lucas Coelho de Assis ${ }^{3}$

\begin{abstract}
Resumo
O presente trabalho consiste no levantamento das espécies da família Arecaceae no Rio Grande do Sul. Foram reconhecidas 15 espécies nativas no estado (Bactris setosa, Butia catarinensis, B. eriospatha, B. exilata, B. lallemantii, B. odorata, B. paraguayensis, B. witeckii, B. yatay, Euterpe edulis, Geonoma gamiova, G. schottiana, Syagrus romanzoffiana, Trithrinax acanthocoma e T. brasiliensis), três espécies foram excluídas da flora gaúcha (Acrocomia aculeata, A. totai e Butia microspadix); três binômios foram considerados sinônimos (Butia missionera, B. pulposa e B. quaraimana); Butia stolonifera foi considerada espécie dúbia; além disso, são apresentados dois híbridos naturais, sendo um deles descrito no presente trabalho $(\times$ Butyagrus alegretensis e $\times$ Butyagrus nabonnandii).
\end{abstract}

Palavras-chave: espécies, Palmae, taxonomia.

\begin{abstract}
This paper is a survey of Arecaceae family in Rio Grande do Sul state. We recognize 15 native species in this state (Bactris setosa, Butia catarinensis, B. eriospatha, B. exilata, B. lallemantii, B. odorata, B. paraguayensis, B. witeckii, B. yatay, Euterpe edulis, Geonoma gamiova, G. schottiana, Syagrus romanzoffiana, Trithrinax acanthocoma and T. brasiliensis). Three species were excluded from Rio Grande do Sul flora (Acrocomia aculeata, A. totai and Butia microspadix), three names were considered synonyms (Butia missionera, B. pulposa and B. quaraimana); Butia stolonifera was considered a doubtful specie. Two natural hybrids are recognized, one of them being described in this work (x Butyagrus alegretensis and $\times$ Butyagrus nabonnandii).

Key words: Palmae, species, taxonomy.
\end{abstract}

\section{Introdução}

A família das palmeiras, Arecaceae, forma um dos principais troncos da evolução das monocotiledôneas, sendo constituída atualmente por 252 gêneros e aproximadamente de 2.600 espécies (Dransfield et al. 2008). No Brasil ocorrem naturalmente 38 gêneros e cerca de 270 espécies (Lorenzi et al. 2010). A sistemática da família é tradicionalmente baseada nas características morfológicas dos estipes, das folhas, dos frutos, das flores, nas particularidades anatômicas dos seus órgãos, em comparação de características citológicas e histológicas, estudos das distribuições geográficas atuais e história da evolução da família e seus gêneros (Henderson et al. 1995; Dransfield et al. 2008).
As palmeiras representam a terceira família botânica mais importante para o ser humano (Johnson 1998). Possuem ampla distribuição, abundância, produtividade e diversidade de usos, é de grande importância alimentar, medicinal, sócio-cultural e econômica para populações locais (Zambrana et al. 2007).

Esta família teve no Período Geológico Terciário (Eoceno) o seu auge de desenvolvimento e disseminação pelo planeta, ocupando todos os atuais continentes. Formaram densos e luxuriantes bosques no atual território da Finlândia, da Rússia europeia, Alemanha, Ásia, África e Américas, constituindo dois terços da vegetação arbórea (Bondar 1964; Dransfield et al. 2008). Na atual dispersão, as palmeiras se adaptaram a uma variedade de clima e

\footnotetext{
${ }^{1}$ Universidade Federal de Santa Maria, Herbário do Dep. Ciências Florestais (HDCF), Av. Roraima 1000, 97105-900, Santa Maria, RS, Brasil.

${ }^{2}$ Colégio Politécnico da Universidade Federal de Santa Maria, Av. Roraima 1000, 97105-900, Santa Maria, RS, Brasil.

${ }^{3}$ Baden-Württembergisches Brasilien-Zentrum der Universität Tubingen. Wilhelmstr. 113, D-72074, Tübingen, Alemanha.

${ }^{4}$ Autor para correspondência: kpsoares@gmail.com
} 
solo, porém é na região equatorial quente e úmida que elas prosperaram em maior número de espécies, especialmente na Malásia, Ásia tropical e América equatorial (Bondar 1964; Henderson et al. 1995; Lorenzi et al. 2010). No entanto, muitas espécies conseguem prosperar em locais de clima temperado, como no estado do Rio Grande do Sul, onde as formações campestres e florestais encontram-se em permanente competição e são condicionados sob fortes influências ambientais, sobretudo as climáticas, que sofreram transformações ao longo do tempo, notavelmente durante o Quaternário.

Baseando-se principalmente em evidências fitogeográficas, alguns naturalistas viajantes do final do século XIX concluíram que o tipo de vegetação campestre era mais antigo e a floresta seria um processo mais recente, decorrente das mudanças no clima para condições mais úmidas e quentes (Lindman 1906; Rambo 1956; Hueck 1972; Klein 1975).

Ao analisar a ocorrência de palmeiras no estado do Rio Grande do Sul, nota-se que a maioria das espécies pertence aos ambientes do tipo campestre ou de áreas abertas, formando palmares característicos; algumas destas espécies não ocorrem em nenhum outro estado da federação (Butia exilata Deble \& Marchiori, B. lallemantii Deble \& Marchiori, B. witeckii K. Soares \& S. Longhi, B. yatay (Mart.) Becc. e Trithrinax brasiliensis Mart.). Dificilmente há interação entre as diferentes espécies, com exceção das palmeiras que habitam as formações silváticas (Rossato 2007). Estas últimas nunca compõem os chamados palmares, pois crescem no interior de florestas e, no estado gaúcho, a maioria delas não se afasta muito do Oceano ou da bacia de um grande rio ou laguna, com exceção do Syagrus romanzoffiana (Cham.) Glassman., que, ao entrar em contato com as palmeiras do gênero Butia (Becc.) Becc., pode gerar híbridos naturais (Rossato 2007).

Este trabalho apresenta o levantamento completo das palmeiras do Rio Grande do Sul, com descrição, tratamento taxonômico, ilustrações inéditas, comentários e a ocorrência natural das espécies nativas, bem como, das espécies erroneamente citadas para o estado, híbridos naturais e sinonímias, com objetivo de elucidar equívocos que ocorrem nas identificações e ocorrência das espécies nativas do Rio Grande do Sul.

\section{Material e Métodos}

O levantamento, identificação e descrição das palmeiras do Rio Grande do Sul foram baseados em materiais coletados por meio de expedições botânicas realizadas entre os anos 2010 e 2012 que contemplou todas as regiões fisiográficas do estado, cujos espécimes foram depositados no Herbário do Departamento de Ciências Florestais da Universidade Federal de Santa Maria (HDCF), também foram consultados os protólogos e base bibliográfica atualizada, como Dransfield et al. (2008) e Lorenzi et al. (2010), além dos Herbários CTES*, HAS, HBR, HPL, ICN, M*, NY*, P*, PACA, PEL, SMDB e SP. Acrônimos de acordo com Thiers (continuously updated), os marcados com $(*)$ foram analisadas apenas copias digitalizadas.

Foram incluídas também neste trabalho as espécies nativas do Brasil, frequentemente citadas para o Rio Grande do Sul, mas que não ocorrem naturalmente no estado, junto da qual são apresentadas justificativas para a exclusão destas espécies da flora gaúcha.

Materiais herborizados de Arecaceae em muitos casos não permitem a identificação das espécies, especialmente as do gênero Butia, isto porque muitas coletas são incompletas, trazendo apenas as partes vegetativas, sem a inclusão do endocarpo ou das flores pistiladas. Outro motivo é que a coleta de material botânico dos indivíduos mais altos é um tanto trabalhosa e, por terem maiores dimensões, torna-se mais difícil a herborização, deste modo, muitas dessas coletas são exemplares jovens ou de pequeno porte, que consequentemente apresentam menores medidas das partes vegetativas, ou então, inclui-se apenas um segmento destas partes, fato que também foi exposto por Glassman (1970).

As medições e descrições das partes vegetativas seguiu Tomlinson (1961) e Noblick \& Lorenzi (2010). Utilizou-se a terminologia "pina" para cada segmento das folhas pinadas e apenas "segmento" para as folhas palmado-flabeliformes. As medidas de frutos, endocarpos e flores foram tomadas com auxilio de paquímetro digital, as demais partes vegetativas foram medidas com trena. Medidas referentes à largura da bráctea peduncular e da bainha das folhas foram tomadas na sua porção mais larga e o diâmetro do estipe entre 10-20 cm acima do solo.

As figuras que apresentam a distribuição natural das espécies foram feitas baseadas em observações pessoais dos autores durante as expedições botânicas, em trabalhos publicados (corrigindo a identificação das espécies quando necessário) e em coletas depositadas em herbários, no qual é apresentada a ocorrência em nível municipal, citando-se as coordenadas geográficas 
no texto ou em "material examinado" para as principais populações das espécies gregária.

Os gêneros e espécies foram apresentados em ordem alfabética, no entanto, os táxons pertencentes ao gênero Butia foram dispostos nas pranchas conforme sua semelhança e características morfológicas mais próximas, visando desta forma facilitar a identificação das espécies, uma vez que o gênero é constituído por um complexo de espécies e variedades de difícil delimitação taxonômica, no qual parece encontrar-se em plena atividade evolutiva, ainda em processo de fixação dos caracteres morfológicos (Soares 2013).

As informações presentes na chave contemplam a identificação dos espécimes em campo e em material herborizado completo.

\section{Resultados e Discussão}

Arecaceae Schultz Sch., Nat. Syst. Pflanzenr. 317 (1832) (nome mantido). Palmae Juss., Gen. Pl. 37 (1789). Tipo: Areca L.

\section{Chave de identificação das espécies nativas do Rio Grande do Sul}

1. Palmeiras com folhas palmado-flabeliformes.

2. Folhas verde escuras na face adaxial; segmentos $80-103 \times 4,5-6 \mathrm{~cm}$, terminados em pontas duplas rígidas e pungentes, $6-16 \mathrm{~cm}$ de bifurcação (até 1/5 do compr. total do segmento); pecíolo mais de $3 \mathrm{~cm}$ larg.; bainha com espinhos de 12-25 cm compr., rígidos e longo persistentes

6.1 Trithrinax acanthocoma

2'. Folhas verde-oliva ou glaucas na face adaxial; segmentos 40-75 × 1,5-4,0 cm, terminados em pontas duplas flexíveis e não pungentes, $17-35 \mathrm{~cm}$ de bifurcação (ca. $1 / 2$ compr. total do segmento); pecíolo menos de $3 \mathrm{~cm}$ larg.; bainha com espinhos de 6-10-(14) cm compr., quebradiços e decíduos após a morte das folhas

6.2 Trithrinax brasiliensis

1'. Palmeiras com folhas pinadas.

3. Raque foliar e pinas armadas

1.1 Bactris setosa

3'. Raque foliar e pinas inermes.

4. Bráctea peduncular papirácea; infrutescência infrafoliar, raramente interfoliar; epicarpo dos frutos preto, roxo-escuro ou purpúreo quando maduros; mesocarpo purpúreo.

5. Estipe mais de $10 \mathrm{~cm}$ diâm.; raque foliar mais de 45 pinas de cada lado; bainha das folhas com 1-1,5 m compr.; ráquilas cobertas por tricomas; flores não imersas em alvéolos nas ráquilas; eófilo das plântulas palmado

3.1 Euterpe edulis

5. Estipe até $4 \mathrm{~cm}$ diâm.; raque foliar menos de 40 pinas de cada lado; bainha das folhas com 0,17-0,33 m compr.; ráquilas não cobertas por tricomas; flores imersas em alvéolos nas ráquilas; eófilo das plântulas bífido.

6. Raque foliar de indivíduos adultos com 11-40 pinas de cada lado; pinas com distribuição uniforme até $3 \mathrm{~cm}$ larg. (exceto em indivíduos jovens, que podem apresentar pinas mais largas) 4.2 Geonoma schottiana

6'. Raque foliar de indivíduos adultos com até 11 pinas de cada lado; pinas com distribuição irregular, intercalada com pinas de larguras variadas, $1-11 \mathrm{~cm}$ larg. ......

4.1 Geonoma gamiova

4'. Bráctea peduncular lenhosa; infrutescência interfoliar; epicarpo dos frutos nunca preto, roxoescuro ou purpúreo quando maduros; mesocarpo amarelo.

7. Pinas inseridas em diferentes planos (ângulos) sobre a raque, conferindo à folha um aspecto plumoso 5.1 Syagrus romanzoffiana

7'. Pinas inseridas num mesmo plano ou em planos muito pouco diferenciados, formando um "V" sobre a raque foliar sem, no entanto, conferir um aspecto plumoso à folha.

8. Bráctea peduncular da inflorescência contendo sulcos (frisada) longitudinais; margens dos pseudopecíolos com dentes inconspícuos.

9. Estipe até $30 \mathrm{~cm}$ diâm.; raque foliar até $220 \mathrm{~cm}$ compr.; parte expandida da bráctea peduncular 56-64 cm compr. $13 \times$ Butyagrus alegretensis 
9'. Estipe mais de $40 \mathrm{~cm}$ diâm.; raque foliar 230-330 cm compr.; parte expandida da bráctea peduncular $100-160 \mathrm{~cm}$ compr. $14 \times$ Butyagrus nabonnandii

8'. Bráctea peduncular da inflorescência sem sulcos, apenas levemente estriada longitudinalmente; margens dos pseudopecíolo com dentes conspícuos.

10. Plantas cespitosas, raramente com estipe solitário

11. Bráctea peduncular coberta por indumento esbranquiçado ou marrom-avermelhado; endocarpo oval, 1-2,2 × 0,7-1,5 cm; ocorre na região norte do estado (Rondinha e Ronda Alta)

2.1 Butia exilata

11'. Bráctea peduncular glabra; endocarpo alongado, turbinado ou elipsóide, 2,0-3,0 × 0,9-2,0 cm; ocorre na região da campanha do RS (Alegrete, Manoel Viana, São Francisco de Assis, Rosários do Sul e Santana do Livramento)

2.2 Butia lallemantii

10'. Plantas com estipe solitário, nunca cespitosas

12. Flores pistiladas com até $9 \mathrm{~mm}$ compr.; endocarpo globoso a estreito ovóide

13. Bráctea peduncular revestida por um denso indumento lanuginoso, de cor castanhoavermelhada persistente mesmo após a queda da bráctea 2.4 Butia eriospatha

13'. Bráctea peduncular nunca revestida por um denso indumento lanuginoso, quando muito, apenas por um indumento pruinoso

14. Estipe 0,2-2-(4) m compr., 15-43 cm diâm.; bráctea peduncular com ápice apiculado; endocarpo 1,2-1,4 × 0,8-1,2 cm, estreito ovóide; ocorre no litoral norte do RS

2.3 Butia catarinensis

14'. Estipe 2-10 m compr., 32-60 cm diâm.; bráctea peduncular com ápice agudo; endocarpo 1,3-2,2 × 1,3-2 cm, globoso a ligeiramente ovóide; ocorre no litoral e centro-sul do RS 2.5 Butia odorata

12'. Flores pistiladas com mais de $9 \mathrm{~mm}$ compr.; endocarpo elipsóide, elíptico-angular a turbinado

15. Estipe subterrâneo ou até $2 \mathrm{~m}$ alt.; parte expandida da bráctea peduncular $20-50 \mathrm{~cm}$ compr.; raque da inflorescência $13-40 \mathrm{~cm}$ compr. 2.6 Butia paraguayensis

15'. Estipe 3-16 m alt.; parte expandida da bráctea peduncular 50-85 cm compr.; raque da inflorescência 40-72 cm compr.

16. Folhas, 43-61 pinas de cada lado da raque, as da parte mediana 40-65 compr.; frutos pesando 23,61-57,03 g; endocarpo elíptico-angular, 2,8-3,8 × 1,7-2,6 cm, pesando $3,61-15,80 \mathrm{~g}$ (pirênio) com 3 quinas longitudinais visíveis; ocorre na região central do RS

2.7 Butia witeckii

16'. Folhas, (57)-63-78 pinas de cada lado da raque, as da parte mediana (58)-65-77 cm compr.; frutos pesando 7,72-23,48 g; endocarpo alongado, elipsoide ou turbinado, 1,8-2,8 × 1,0-1,7 cm, pesando 1,15-3,52 g (pirênio), sem quinas longitudinais; ocorre em Quaraí, Giruá, e é cultivado na fronteira com a Argentina

2.8 Butia yatay

Gêneros e espécies de Arecaceae nativas do Rio Grande do Sul

1. Bactris Jacq. ex Scop., Intro. Hist. nat. 70 (1777). Lectótipo: B. minor Jacq., nom illeg. [B. guineensis (L) H. E. Moore].

1.1 Bactris setosa Mart., Hist. Nat. Palm. 2: 94, 1926. Tipo: BRASIL. RIO DE JANEIRO: s. loc., s.d., $C$. Martius s.n. (holótipo, M; F neg. 18628, n.v.).

Figs. 1a-c; 8a

Palmeira cespitosa. Estipes $0,8-6 \times 0,03-0,05$ $\mathrm{m}$, espinhos 2-8 cm compr., dispostos em torno dos entrenós. Folhas pinadas, 4-8 por estipe, bainha, pecíolo, raque e pinas moderadamente armados; espinhos até $5 \mathrm{~cm}$ compr., achatados; bainha 20-30 cm compr.; pecíolo 0,2-1,0 cm compr.; raque $0,5-$ 1,5 m compr., 19-60 pinas de cada lado, distribuídas irregularmente ao longo da raque e dispostas em mais de um plano. Inflorescência interfoliar, ramificada; pedúnculo $15-30 \mathrm{~cm}$ compr.; profilo 9-22 cm compr.; bráctea peduncular espinhenta, tomentosa, $20-55 \mathrm{~cm}$ compr.; raque $10-20 \mathrm{~cm}$ compr.; 10-27 ráquilas, até $15 \mathrm{~cm}$ compr. Flores masculinas e femininas na mesma inflorescência, 3 pétalas e 3 sépalas. Frutos pretos ou purpúreos quando maduros, 1-2,5 cm diâm, globosos; mesocarpo suculento; endocarpo ósseo, 0,9-2,2 cm diâm., 3 poros de germinação e uma única semente; endosperma homogêneo. Eófilo bífido. 

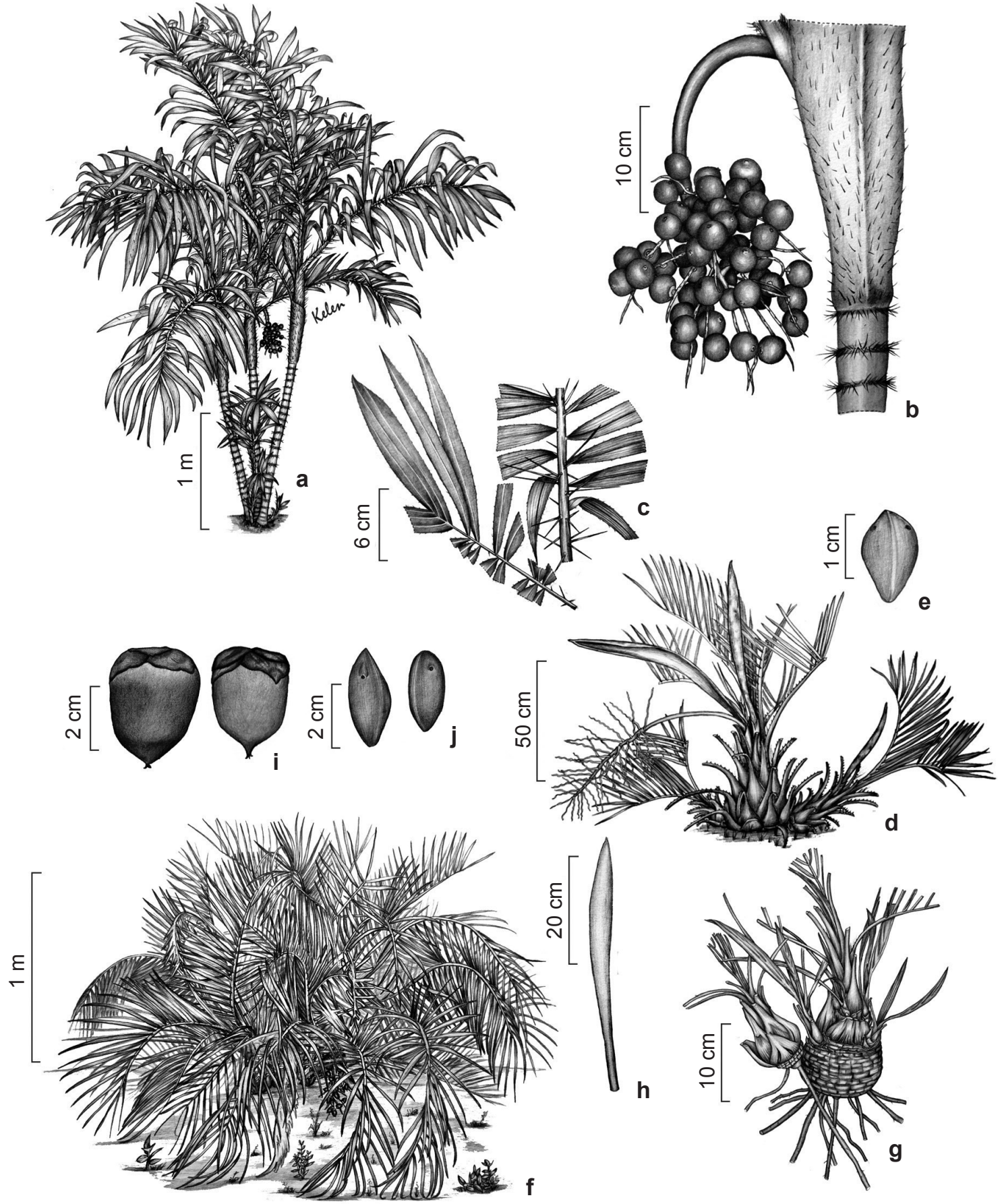

Figura 1 - a-c. Bactris setosa Mart. - a. hábito; b. detalhe da infrutescência; c. detalhe das folhas (K. Soares \& Witeck 29). d-e. Butia exilata Deble \& Marchiori - d. hábito com folhas parcialmente removidas mostrando a espata com indumento externo; e. endocarpo (K. Soares et al. 41). f-j. Butia lallemantii Deble \& Marchiori - f. hábito; g. detalhe dos perfilhos em indivíduo jovem; h. espata glabra; i. frutos; j. endocarpo (K. Soares \& Witeck 37, exceto g- fotografia de K. Soares). Figure 1 - a-c. Bactris setosa Mart. - a. habit; b. infructescence detail; c. leaf detail (K. Soares \& Witeck 29). d-e. Butia exilata Deble \& Marchiori - d. habit with removed leaves showing peduncular bract with indumentum; e. endocarp (K. Soares et al. 41). f-i. Butia lallemantii Deble \& Marchiori - f. habit; g. detail of cluster stem in young plant; h. peduncular bract glabrous; i. fruits; j. endocarp (K. Soares \& Witeck 37, except g - image taken by K. Soares). 
Material examinado: Candelária, morro Três Irmãos, 25.VIII.2012, fr., K. Soares \& L. Witeck 29 (HDCF 6267). Candelária, 9.IX.1984, Waechter 2028 (ICN 61304). Dom Pedro de Alcântara, 3.I.2000, C. F. Junnitz 20 (ICN 120600). Guaíba, 3.XII.2005, fr., L. F. Lima 318 (ICN 144128). Maquiné, 16.X.1993, fl., L. Sevegnani s.n. (ICN 103851). Santa Cruz do Sul, 16.XI.1985, fl., J. Waechter 2137 (ICN 64361). Viamão, 25.II.1968, fr., B. Irgang s.n. (ICN 4760). Torres, 11.VII.1972, B. Irgang \& A. Giardi, s.n. (ICN 27999). Três Cachoeiras, 9.I.1992, $R$. Záchia 725 (ICN 119313). Terra de Areia, 4.XI.1972, $A$. R. Shultz et al. s.n. (ICN 20757). Vera Cruz, 29.XI.1987, fl., J. A. Jarenkow et al. 804 (PEL 9935).

Espécie típica de regiões litorâneas florestadas e úmidas, do Sudeste e Sul do Brasil (Lorenzi et al. 2004). No RS é mais frequente no litoral norte do estado, entrando pela Depressão Central até o município de Cachoeira do Sul, onde sua frequência diminui conforme se afasta do litoral. Os frutos desta espécie, conhecida popularmente como tucum, são muito saborosos.

2. Butia (Becc.) Becc., l'Agric. Colon. 10: 489 (1916). Lectótipo: B. capitata (Mart.) Becc.

2.1 Butia exilata Deble \& Marchiori, Balduinia 30: 5. 2011. Tipo: BRASIL. RIO GRANDE DO SUL: Rondinha, $2 \mathrm{~km}$ do Parque Estadual de Rondinha. 22.XII.2010. L.P. Deble; A.S. Oliveira-Deble; J.N.C. Marchiori \& F.S.Alves 13422 (Parátipo CTES!).

Figs. 1d-e; $8 \mathrm{~b}$

Palmeira cespitosa. Estipe subterrâneo, muito curto, ou raramente até $1,5 \mathrm{~m}$. Folhas pinadas, 4-13 por estipe, arqueadas, 80-160 cm compr; bainha 20-35 × 5-10 cm; pseudopecíolo 30-52 × 1,2-2 cm, com margens denteadas e fibras achatadas; raque $45-135 \mathrm{~cm}$ compr.; pinas verde-azuladas, um pouco discolores, distribuídas uniformemente ao longo da raque, inseridas em um mesmo plano, dispostas em "V", 25-44 de cada lado, rígidos e com mechas de ramento na inserção com a raque na parte basal; pinas da parte mediana da raque $30-55 \times 0,8-1,5 \mathrm{~cm}$. Inflorescência ramificada interfoliar; pedúnculo 19-42 cm compr.; profilo 19-40 cm compr., aparente entre as bainhas; bráctea peduncular lenhosa, coberta na parte exterior por indumento esbranquiçado ou marrom-avermelhado, às vezes somente pruinosa (na sua ocorrência mais a leste), 50-90 cm compr., parte expandida $32-50 \times 3,5-6,5 \mathrm{~cm}$; raque da inflorescência 25-45 cm compr., 18-38 ráquilas que medem 9-25 cm compr. Flores amarelas ou arroxeadas; estaminadas $10-12 \mathrm{~mm}$ compr.; pistiladas $12-16$ $\mathrm{mm}$ compr. Frutos alongados, com forma de cone, amarelos, verde-amarelados ou arroxeados quando maduros, 3-4 × 1,6-2 cm; mesocarpo suculento, fibroso; endocarpo oval, 1,2-2,2 $\times$ 0,7-1,5 cm, ósseo, 1-3 sementes, endosperma homogêneo. Eófilo simples.

Material examinado: Passo Fundo, $1 \mathrm{~km}$ da encruzilhada Sarandi/Passo Fundo, 20.V.1977, fr., J. Mattos et al. 17212 (HAS 67377). Ronda Alta, beira da estrada, S 27050'24,9" W 52 50 '59,6”, 21.IX.2012, fl. e fr., $K$. Soares et al. 42 (HDCF). Ronda Alta, $10 \mathrm{~km}$ de Ronda Alta, 14.XI.1976, A. Alvarez \& B. Irgang 13 (ICN 34137). Ronda Alta, beira da estrada, 21.IX.2012, fr., $K$. Soares et al. 42 (HDCF). Ronda Alta, em direção a Nataline, 9.XII.1975, fl., B. Irgang et al. (ICN 26908). Veranópolis, cultivada na Avenida, 6.VI.1977, fr., J. Mattos 17302 (HAS 67379).

Ocorre numa pequena área nas proximidades do Parque Estadual de Rondinha, nos municípios de Rondinha e Ronda Alta, na vegetação do tipo savânico, em campos ou na beira da estrada, onde está bastante ameaçada. Morfologicamente esta espécie é muito próxima de Butia lallemantii e $B$. paraguayensis, sendo a espata recoberta por indumento e endocarpos ovais as características que a diferencia das demais, na sua distribuição mais a oeste, onde são cultivados, os indivíduos apresentam porte elevado, estipe solitário (até $1,5 \mathrm{~m}$ ) e espata mais densamente recoberta por indumento. Em princípio não se pode confirmar, conforme a descrição original da espécie (Deble et al. 2011), a origem das plantas cultivadas que, quanto ao porte, mostram-se mais próximas de $B$. paraguayensis, outra razão para esta dúvida é que frequentemente são cultivados butiazeiros na região serrana do Rio Grande do Sul, como Nova Prata e Veranópolis, e no planalto, como em Passo Fundo, com características idênticas aqueles cultivados em Ronda Alta, ou seja, com a bráctea peduncular recoberta por indumento e flores pistiladas maiores que $9 \mathrm{~mm}$. Apesar desse indumento pruinoso da bráctea peduncular aparecer ocasionalmente em outras espécies como B. odorata e B. paraguayensis (São Manuel - SP) e esta característica morfológica parecer muito variável, aceita-se $B$. exilata como espécie em vista seu isolamento geográfico e por crescer numa área com fisionomia e solo distintos das espécies B. lallemantii e B. paraguayensis, características dos chamados "campos de areia" do sudoeste do estado e noroeste do Uruguai (Deble et al. 2011; Brussa Santander \& Grela Gonzáles 2007). 
2.2 Butia lallemantii Deble \& Marchiori, Balduinia 9: 2. 2006. Tipo: BRASIL. RIO GRANDE DO SUL: São Francisco de Assis, 12.XII.2003, L.P. Deble; A.S. Oliveira \& J.N.C. Marchiori 1514 (Holótipo SI, n.v.).

Figs. 1f-j; 8c

Palmeira cespitosa. Estipe, até 12, subterrâneos com até $1 \mathrm{~m}$ compr., $25 \mathrm{~cm}$ diâm. Folhas pinadas, 5-12 contemporâneas, $60-160 \mathrm{~cm}$ compr.; bainha 14-21 × 8-12 cm; pseudopecíolo 20-40 cm compr., margens com dentes e fibras achatadas; raque 40-150 cm compr.; pinas dispostas em "V" sobre a raque, 24-40 de cada lado. Inflorescência ramificada interfoliar; pedúnculo $14-40 \mathrm{~cm}$ compr.; profilo, 10-24 cm compr.; bráctea peduncular lenhosa, lisa, 20-52 cm compr., parte expandida $26-36 \times 3-8 \mathrm{~cm}$; raque da inflorescência 25-36 cm compr., com 10-38 ráquilas de 6-33 cm compr. Flores amarelas ou arroxeadas; estaminadas 10 mm compr.; pistiladas 11-15 mm compr. Frutos alongados, amarelos, alaranjados ou vermelhos quando maduros, 2,5-3,5 cm de compr.; mesocarpo suculento, carnoso; endocarpo alongado, turbinado ou elipsoide, 2,0-3,0 × 0,9-1,6 cm, ósseo, contendo 1-3 sementes alongadas; endosperma homogêneo. Eófilo simples.

Material examinado: Alegrete, Cerro do Tigre, 6.I.2007, fl., E. Freitas 98 (ICN 152725). Manoel Viana, $29^{\circ} 35^{\prime} 49.35^{\prime \prime}$ - $-55^{\circ} 22^{\prime} 27.06^{\prime \prime W}$, 2.IX.2012, fl. e fr., $K$. Soares \& L. Witeck 37 (HDCF 6275). Quaraí, "in campus rupestris", I.1945, fr., B. Rambo (PACA 26090). Santana do Livramento, Cerro Palomas, 25.XI.1972, E. Viana et al. (ICN 21019). Santana do Livramento, cerro Armour, 26.III.1976, fr., B. Irgang (ICN 32392). São Francisco de Assis, a $18 \mathrm{~km}$ do trevo de acesso a oeste, 2.III.2007. fr. R. A. Zachia et al. 5873 (SMDB 10364).

Ocorre nos municípios de Alegrete, Manoel Viana, Quaraí, São Francisco de Assis, Santana do Livramento e Rosário do Sul, nos campos arenosos e nas elevações areníticas destes locais; ocorre também, segundo Brussa \& Grela (2007), no departamento de Rivera e Artigas no Uruguai. Butia lallemantii, assim como B. exilata, é muito variável morfologicamente, alguns indivíduos apresentam hábito extremamente cespitoso, estipes subterrâneos, pinas das folhas muito estreitas parecendo uma gramínea, enquanto outros apresentam pinas largas, estipes com poucos ou nenhum perfilho, que chega até $1 \mathrm{~m}$ compr. Talvez a proximidade de ocorrência desta espécie $\operatorname{com} B$. paraguayensis tenha acarretado cruzamentos no passado; ou esta se encontra ainda em processo de fixação dos caracteres de especiação. Os caracteres morfológicos típicos desta espécie pertencem aos indivíduos de menor porte, com pinas estreitas e estipe bastante cespitoso. Frutifica durante todo ano, porém, mais abundantemente no verão. Está muito ameaçada pela expansão das lavouras de soja e monocultura de árvores exóticas.

2.3 Butia catarinensis Noblick \& Lorenzi, Fl. Brazil. Arec: 164. 2010. Holótipo: BRASIL. SANTA CATARINA: Barra do Sul, 29.X.2009, H. Lorenzi \& K. Soares 6760 (Holótipo, HPL!).

Figs. 2a-c; 8d

Estipe $0,2-2,0-(4) \times 0,15-0,43 \mathrm{~m}$ alt. Folhas pinadas, 9-32 contemporâneas; bainha 50-120 $\times 7-15 \mathrm{~cm}$; pseudopecíolo $18-64 \times 1,5-2,4 \mathrm{~cm}$, guarnecido de fibras e dentes fortes na sua margem, de até $4 \mathrm{~cm}$ compr.; raque $65-190 \mathrm{~cm}$ compr., 48-62 pares de pinas; pinas distribuídas uniformemente e inseridas em um ou mais planos pouco discrepantes, formando um "V" sobre a raque, as parte mediana da raque 35-75 × 1,3-2,3 $\mathrm{cm}$. Inflorescência interfoliar; pedúnculo $29-77 \mathrm{~cm}$ $\times 1,6-1,9 \mathrm{~cm}$; profilo $19-47 \times 3,2-5,5 \mathrm{~cm}$; bráctea peduncular glauca, com ápice apiculado, 65-110 cm compr., parte expandida 33-73 × 8-17 cm; eixo da inflorescência 30-60 cm compr.; raque 72-186 $\mathrm{cm}$ compr., com 35-135 ráquilas com 10-45 cm compr. Flores amarelas, arroxeadas, esverdeadas; estaminadas 9-10 mm compr.; pistiladas 5-8(10) $\mathrm{mm}$ compr. Frutos amarelos, alaranjados ou avermelhados quando maduros, 1,4-2,2 × 1,2-2,6 $\mathrm{cm}$, perianto persistente; endocarpo estreito-ovóide com ápice sem bico ou qualquer protuberância, $1,2-1,4 \times 0,8-1,2 \mathrm{~cm}$; sementes, $1-2$, raro 3 ; endosperma homogêneo. Eófilo simples.

Material examinado: Osório, Emboaba, 6.XII.1985, fl., J.L. Waechter 2144 (ICN 64666). Torres, butiazal, 2.X.1975, fl., B. Irgang (ICN 29501). Torres, Lagoa Quadros para Torres, 21.2.1950, B. Rambo (PACA 46001). Torres, na BR 101, $29^{\circ} 21^{\prime} 06,5^{\prime \prime}$ S, 49²4'50,9' W, 7.III.2010, fl. e fr., H. Lorenzi et al. 6839 (HPL). Torres, na BR 101, 9.II.1992, R.A. Záchia 727 (ICN 119314).

No RS ocorre entre os municípios de Torres a Osório. Cresce nas restingas, em solos arenosos e rochosos, em dunas, campos litorâneos, ora de permeio à densa vegetação arbustiva (Reitz 1974). Semelhante à Butia odorata, da qual se diferencia pelo menor porte, que geralmente não ultrapassam os $2 \mathrm{~m}$ alt., pelos frutos, que são menores e mais alongados e pelos endocarpos, que são oblongos ou estreito-ovóides, enquanto que no $B$. odorata ele é redondo ou, às vezes, ligeiramente ovóide. 


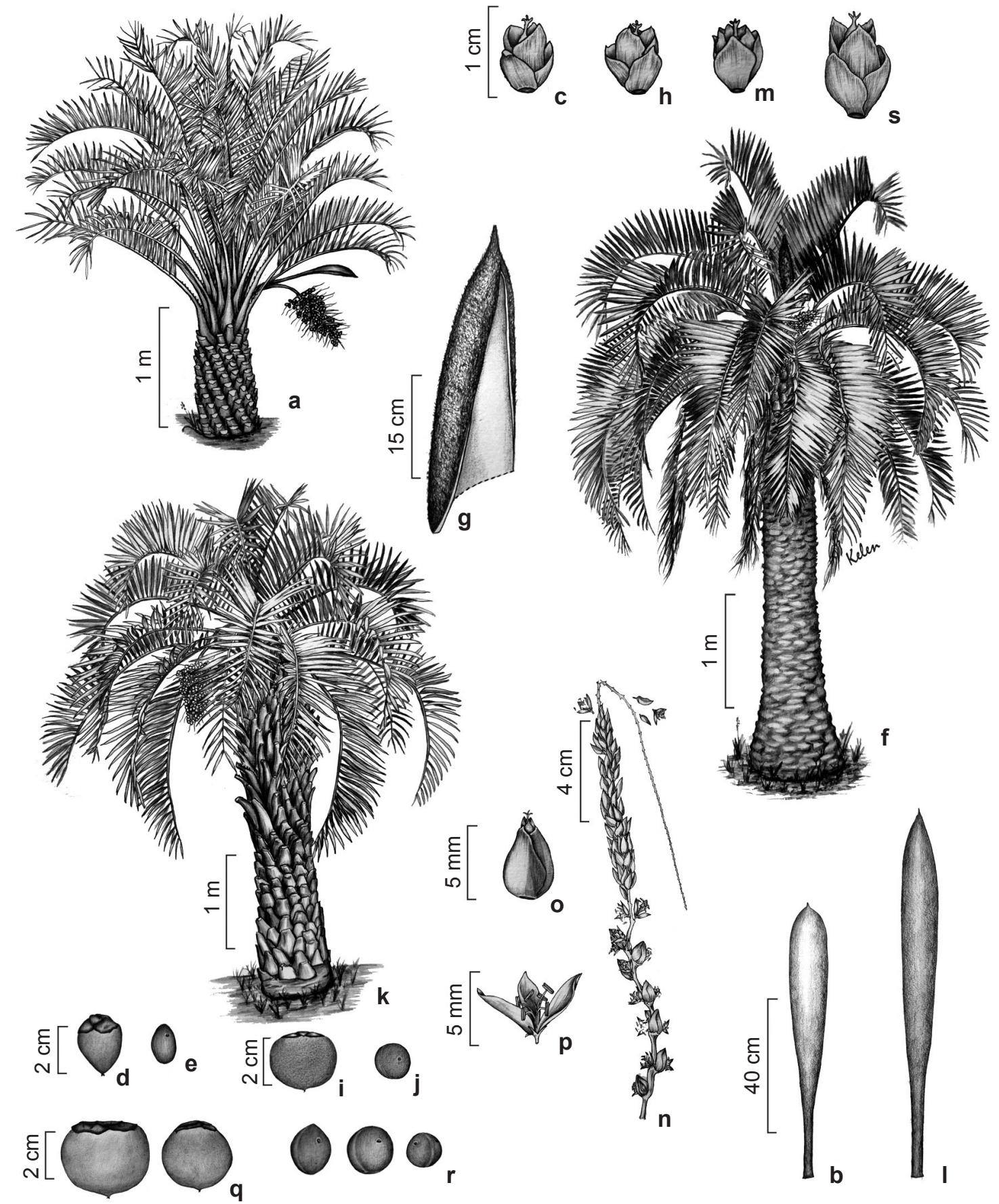

Figura 2 - a-e. Butia catarinensis Noblick \& Lorenzi - a. hábito; b. formato da espata fechada; c. flor pistilada semi aberta; d. fruto; e. endocarpo (Lorenzi et al. 6839). f-j. Butia eriospatha (Mart. Ex Drude) Becc. - f. hábito; g. detalhe da espata aveludada; h. flor pistilada semi aberta; i. fruto; j. endocarpo (K. Soares 30). k-r. Butia odorata (Barb. Rodr.) Noblick - k. hábito; 1. formato da espata fechada; m. flor pistilada; n. raquila; o. flor pistilada; p. flor estaminada; q. frutos; r. endocarpos (K. Soares 38 \& Lorenzi et al. 6837). s. Butia yatay (Mart.) Becc. - s. flor pistilada semi aberta para comparação (K. Soares et al. sn - HDCF 6214).

Figure 2 - a-e. Butia catarinensis Noblick \& Lorenzi - a. habit; b. shape of peduncular bract closed; c. pistillate flower partially open; d. fruit; e. endocarp (Lorenzi et al. 6839). f-j. Butia eriospatha (Mart. Ex Drude) Becc. - f. habit; g. detail of the tomentous peduncular bract; h. pistillate flower partially open; i. fruit; j. endocarp (K. Soares 30). k-r. Butia odorata (Barb. Rodr.) Noblick - k. habit; 1. shape of peduncular bract closed; m. pistillate flower partially open; n. rachillae; o. pistillate flower; p. staminate flower; q. fruits; r. endocarps (K. Soares 38 \& Lorenzi et al. 6837). s. Butia yatay (Mart.) Becc. - s. pistillate flower partially open to comparison (K. Soares et al. sn-HDCF 6214). 
Noblick (2010) cita também diferenças na bráctea peduncular da inflorescência, no qual em $B$. catarinensis a forma alarga-se em direção ao ápice e então, abruptamente termina num curto bico (ápice apiculado); enquanto em $B$. odorata a bráctea é longa e estreita, tendo a parte mais larga próxima da metade do seu compr., estreitando-se lentamente em direção ao ápice (ápice agudo).

2.4 Butia eriospatha (Mart. ex Drude) Becc., L'Agric. Colon. 10: 496. 1916. Tipo: BRASIL, RIO GRANDE DO SUL: sd., A.F.M. Glaziou 8059 (lectótipo, K!).

Figs. 2f-j; $8 \mathrm{e}$

Estipe $2-8 \times 0,4-0,6 \mathrm{~m}$. Folhas pinadas, 20-33 contemporâneas; bainhas $115-140 \mathrm{~cm}$ compr.; pseudopecíolo fibroso e denteado, ca. $70 \mathrm{~cm}$ compr.; raque 1,5-2,2 m compr., com 77-95 pinas regularmente distribuídas, dispostas em "V" sobre a raque; pinas medianas ca. 62 $\times 2,5 \mathrm{~cm}$. Inflorescência interfoliar; pedúnculo 50-85 cm compr.; profilo ca. 40-50 × 4,0-6,0 $\mathrm{cm}$; bráctea peduncular lenhosa, revestida por um denso indumento lanuginoso de cor castanhoavermelhada, $115-135 \mathrm{~cm}$ compr., parte expandida $80-100 \times 14-22 \mathrm{~cm}$; eixo da inflorescência $75-100 \mathrm{~cm}$ compr., com 50-125 ráquilas, as da parte mediana da raque $10-42 \mathrm{~cm}$ compr. Flores amarelas; estaminadas ca. $5 \mathrm{~mm}$ compr.; pistiladas 5-9 mm compr. Frutos globosos 1,8-2,2 × 1,5-3,0 $\mathrm{cm}$; mesocarpo carnoso, pouco fibroso; endocarpo arredondado contendo 1-3 sementes; endosperma homogêneo. Eófilo simples.

Material examinado: Erechim, Campo Erê, 13.XII.2009, L.P. Deble et al. 12854 (CTES). Jaquirana, Jaquirana para São Francisco de Paula, 20.II.1952, fl., B. Rambo (PACA 52018). Nova Prata, cultivado, 26.VIII.2012, fl. K. Soares 30 (HDCF 6268).

Material adicional examinado: SANTA CATARINA: Ponte Alta do Sul, km 315 BR 116, 30.I.1973, fl., $A$. Krapovickas 23065 (ICN 25736).

Ocorre no Planalto Meridional, no PR, SC e RS, sempre em vegetação aberta dos campos do planalto médio, nos campos de cima da serra, às vezes associada à Floresta Ombrófila Mista. Krapovickas \& Dematteis (2008) citam sua ocorrência para a região de Missiones, na Argentina, como planta naturalizada. Facilmente separada das outras espécies nativas do estado por possuir a bráctea peduncular revestida pelo denso tomento lanuginoso. Está na lista de espécies ameaçadas do RS, na categoria "em perigo" (Consema 2003). Incluída também na lista da IUCN na categoria "vulnerável" (IUCN 2012).
2.5 Butia odorata (Barb. Rodr.) Noblick, Palms 55 (1): 48. 2011. Tipo: BRASIL, RIO GRANDE DO SUL: in campis ad, cult. in Jard. Bot. Rio de Janeiro $n^{0} 64$ (destruído, lectótipo, Barb. Rodr., 1891. T. 4a!)

Figs. 2k-r; $8 \mathrm{f}$

Estipe $2-10 \times 0,32-0,6 \mathrm{~m}$, revestido pelos remanescentes das folhas. Folhas pinadas, 13-32 contemporâneas; bainhas $17-23 \mathrm{~cm}$ larg.; pseudopecíolo 30-75 cm compr., margens com fibras e dentes de até $5 \mathrm{~cm}$ compr.; raque 70-200 cm compr., com 35-60 pinas em cada lado, inseridas num mesmo plano ou em mais de um plano pouco diferenciados, formando um "V" sobre a raque; pinas da parte medianas da raque $31-60 \times 1,2-2,5 \mathrm{~cm}$. Inflorescência interfoliar; pedúnculo 40-70 cm compr.; profilo ca. $22 \mathrm{~cm}$ compr.; bráctea peduncular com ápice agudo, lisa ou raramente recoberta por uma camada de cera rala ou espessa, $0,6-1,8 \mathrm{~m}$ compr. total, parte expandida 33-150 ×6-16 cm; eixo da inflorescência $31-130 \mathrm{~cm}$ compr., raque 20-104 cm compr., com 35-141 ráquilas de 15-132 cm compr. Flores amarelas, esverdeadas ou arroxeadas. Flores, estaminadas 5-7 $\mathrm{mm}$ compr.; pistiladas 5-6 mm compr. Frutos com tamanho variável, geralmente mais largo do que comprido, 2,0-3,5 cm × 1,4-4,3 cm; mesocarpo doce-acidulado; epicarpo amarelo, alaranjado, avermelhado ou púrpura quando maduro; endocarpo geralmente globoso, ou levemente ovoide, 1,3-2,2 × 1,3-2 cm, com 1-3 sementes. Eófilo simples.

Material examinado: Barra do Ribeiro, Morro da Formiga, 28.X.2010, fl., R.M. Senna (HAS 47695). Barra do Ribeiro, 7.XII.1967, fl., B. Irgang \& Z. Ceroni 293 (ICN 4665). Barra do Ribeiro, "In silvula arenosa", 14.XI.1948, fl., B. Rambo (PACA 38016). Canguçu (cultivado), 7.IX.2012, fl., K. Soares 39 (HDCF). Encruzilhada do Sul, Fazenda XaFri, Boqueirão, 31.I.2004, fl. e fr., V.F. Kinupp et al. 2867 (ICN 131307). Gravataí, Monte Itacolomí para Gravataí, 11.I.1950, fl., B. Rambo (PACA 45278). Porto Alegre, M. da Glória, 19.IX.1932, fl, B. Rambo (PACA 242). Santa Maria, na UFSM (cultivado), 17.XII.2012, fr., K. Soares 43 (HDCF). Pelotas, na BR 116, 7.III.2010, fl. fr. H. Lorenzi et al. 6837 (HPL). Porto Alegre, 17.XII.1963, fl., J. Mattos 11455 (HAS 67394). Santa Vitória do Palmar, próximo da BR 471, 6.IX.2012, fl., K. Soares 38 (HDCF). Tapes, 28.VIII.2012, K. Soares 32 (HDCF 6270). Tapes, 7.III.2010, fl., fr., H. Lorenzi et al. 6838 (HPL). Viamão, Parque do Itapuã, 15. XI.1977, fl., fr., A. Alvares \& B. Irgang 16 (ICN 34139). Viamão, Vila Fancha, J. Mattos 1963 (HAS 67385). Viamão, Parque Itapuã, Morro da Grota, 31.I.1979, fl., M.L. Porto et al. (HAS 1167). 
Ocorre na faixa litorânea nos municípios desde Palmares do Sul, Viamão e Porto Alegre, no estado do RS, até o sudeste do Uruguai, tanto em restingas como nos campos e cerros próximos do litoral e na divisa do município de

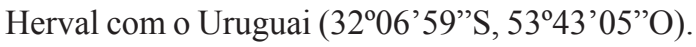
Frequente é a sua presença ao longo das estradas, disseminadas, não intencionalmente, pelo homem e pela fauna a partir do hábitat e quintais. A espécie foi provavelmente introduzida, desta mesma forma, nos pontos mais altos do escudo rio-grandense, visto que, no centro desta região fitogeográfica, ela não forma os chamados butiazais (exceto naqueles municípios da encosta, próximos do litoral como Amaral Ferrador, Camaquã, Cristal e Encruzilhada do Sul). Trata-se de uma das palmeiras mais cultivadas nos jardins e pomares do centro e sul do RS, seu cultivo também foi muito difundido no exterior devido a sua adaptação ao frio (Noblick 2010). Na região de Pedras Altas, a espécie é frequentemente encontrada ao longo da antiga linha de trem (31 ${ }^{\circ} 51^{\prime} 4.05^{\prime \prime}$ S, $\left.53^{\circ} 21^{\prime} 27.63^{\prime \prime} \mathrm{O}\right)$; para esta mesma região, Rambo (1956) citou sua ocorrência "ao pé do Cerro Chato, no Vale do Arroio Santa Maria, galho gerador do Piratini". Em quase todas as regiões em que é cultivada podem ser vistos híbridos desta espécie com Syagrus romanzoffiana (Cham.) Glassman. Esta espécie vem sendo, ao longo dos anos, selecionada pelos habitantes do estado, que escolhem para plantar nos quintais aqueles indivíduos que produzem os frutos maiores e mais doces (Soares \& Witeck 2009).

2.6 Butia paraguayensis (Barb. Rodr.) L. H. Bailey, Gentes Herb. 4: 47. 1936. Tipo: PARAGUAY, "in campis in regione cursus superioris fluminis Apa", Hassler 8554 (Holótipo G!). $\quad$ Figs. 3a-f; 8g

Estipe subterrâneo ou até $2 \mathrm{~m}$ alt., 10-35 cm diâm. Folhas pinadas, 6-23 contemporâneas; bainha $20-70 \times 11 \mathrm{~cm}$; pseudopecíolo $42-70 \mathrm{~cm}$ compr., margens providas de fibras e dentes com até $4 \mathrm{~cm}$ compr.; raque $57-152 \mathrm{~cm}$ compr., com 33-44 pinas de cada lado; pinas da parte mediana da raque $50-70 \times 0,8-2,0 \mathrm{~cm}$. Inflorescência interfoliar; pedúnculo 30-60 cm compr.; profilo lanceolado $20-26 \mathrm{~cm}$ compr.; bráctea peduncular glauca, $32-82 \mathrm{~cm}$ compr., parte expandida $20-60$ $\mathrm{cm} \times 3-10 \mathrm{~cm}$; raque da inflorescência $13-40 \mathrm{~cm}$ compr., com 15-79 ráquilas de 6-40 $\mathrm{cm}$ compr.. Flores amarelas, esverdeadas ou arroxeadas; estaminadas 6-10 $\mathrm{mm}$ compr.; pistiladas $8-16$ $\mathrm{mm}$ compr., geralmente maiores que $10 \mathrm{~mm}$.
Frutos cônicos ou ovoides, amarelos, esverdeados, avermelhados, arroxeados ou alaranjados quando maduros, 2,8-4,0 cm $\times 2,0-3,0 \mathrm{~cm}$; endocarpo alongado, 2,0-2,8 × 0,8-1,5 cm; sementes $1-3$, endosperma homogêneo. Eófilo simples.

Material selecionado: Maçambará, campo dos butiás, $29^{\circ} 02^{\prime} 39,5^{\prime \prime}$ 'S, 55²0'49, 6”'W, 6.IV.2012, fl. fr., K. Soares et al. 1 (HDCF 6225).

Material adicional examinado: BRASIL, MATO GROSSO DO SUL, São Manuel para Santa Maria da

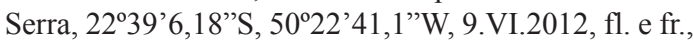
K. Soares \& R. Pimenta 4 (HDCF 6228). SÃO PAULO, São Manuel - SP, 10.VI.2012, fl., K. Soares \& R. Pimenta 17 (HDCF 6241).

Ocorre no oeste de SP, MS, PR, RS, também no Paraguai, Argentina e Uruguai. Noblick (2010) a cita também para o sudoeste de MG. No RS a espécie foi encontrada até o momento, somente na divisa dos municípios de Maçambará e Unistalda onde forma uma densa população nos cerros e no campo arenoso (Deble et al. 2011), no entanto, está muito ameaçada pela pecuária, pela forte predação das suas sementes pelos insetos e pela erosão no frágil solo da região. Para alguns botânicos esta espécie é uma variedade anã de B. yatay (Mart.) Becc. (Beccari 1916); ambos os táxons apresentam semelhanças no tamanho e forma dos seus frutos, endocarpo e flores; no entanto, vegetativamente suas medidas são consideravelmente menores que as de B. yatay. Frutifica durante quase todo ano, com maior abundância no verão. Está na lista de espécies ameaçadas do RS, na categoria "em perigo" (Consema 2003).

2.7 Butia witeckii K. Soares \& S. Longhi. Ci. Fl. 21 (2): 204. 2011. Tipo: BRASIL. RIO GRANDE DO SUL: Quevedos, $2 \mathrm{~km}$ ao norte da Usina de Quebra Dentes, $29^{\circ} 22^{\prime} 07,17^{\prime \prime} \mathrm{S}, 54^{\circ} 00^{\prime} 45,31^{\prime \prime} \mathrm{W}$, 24.III.2011, K. Soares et al. s.n. (HDCF 6213!).

Figs. 3g-k; $8 \mathrm{~h}$

Estipe 2,5-6,0 × 0,24-0,35 m. Folhas pinadas, 14-25 contemporâneas; bainha 37-50 × 9-13 cm; pseudopecíolo $27-45 \times 1,8-2,8 \mathrm{~cm}$, armado; raque das folhas, $100-170 \times 1,2-2,3 \mathrm{~cm}$, frequentemente torcida devido à ação do vento, com 43-61 pinas de cada lado; pinas da parte mediana da raque 40-65 × 2,3-2,8 cm. Inflorescência interfoliar; pedúnculo 56-62 × 1,7-2,0 cm; profilo $38 \times 5,3$ $\mathrm{cm}$; bráctea peduncular glauca, $118-128 \mathrm{~cm}$ compr. total, parte expandida 50-85 $\times 7,8-9,7 \mathrm{~cm}$; raque da inflorescência 40-63 cm compr., com 66-85 ráquilas, as da parte mediana medindo 21,5-38 $\mathrm{cm}$ compr. Flores amarelas ou esverdeadas; 

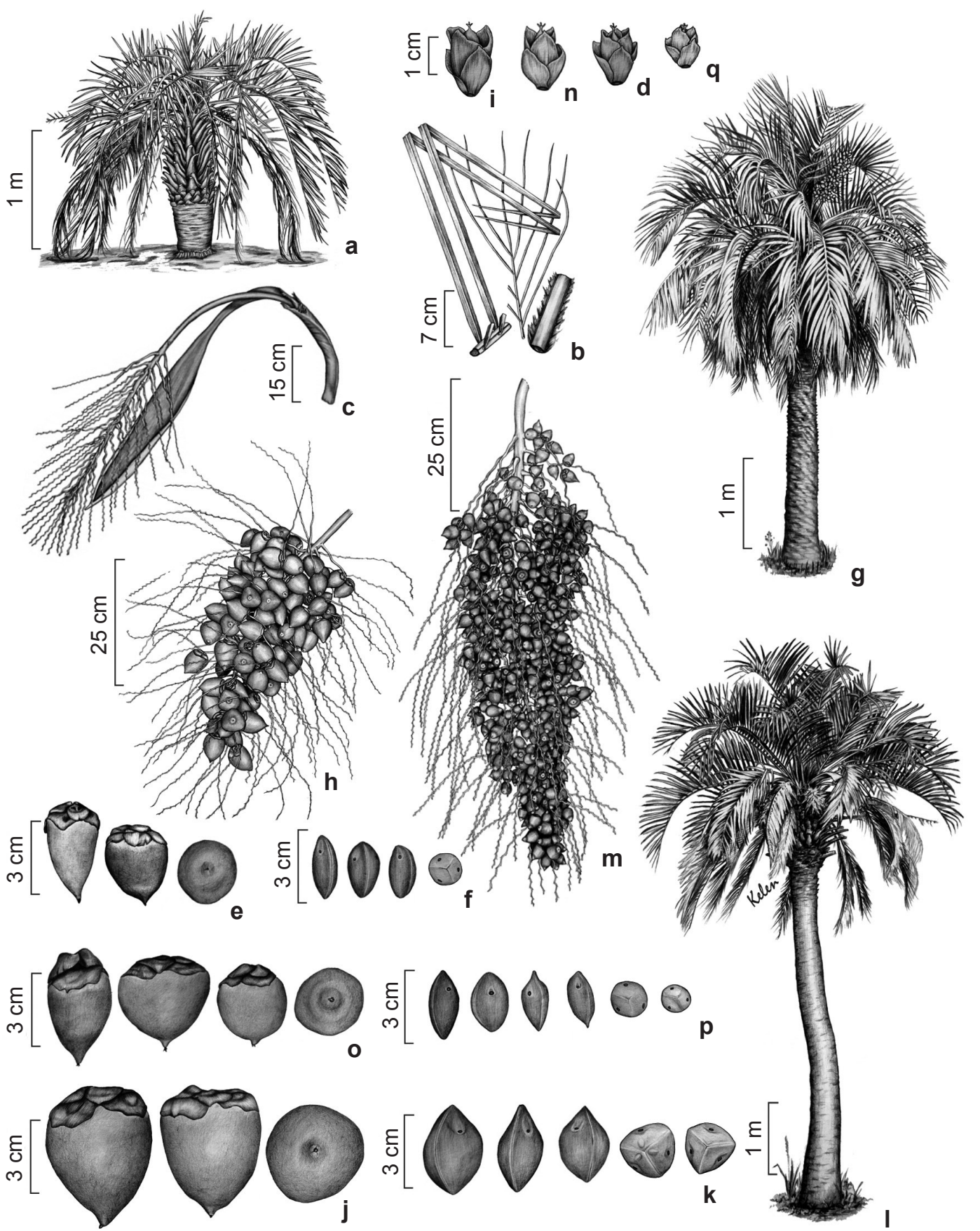

Figura 3 - a-f. Butia paraguayensis (Barb. Rodr.) L. H. Bailey - a. hábito de um velho indivíduo; b. detalhe da extremidade e parte mediana da folha e pseudopecíolo; c. inflorescência; d. flor pistilada semi aberta; e. frutos; f. endocarpos (K. Soares et al. 1). g-k. Butia witeckii K. Soares \& S. Longhi - g. hábito; h. infrutescência; i. flor pistilada semi aberta; j. frutos; k. endocarpos (K. Soares et al. sn - ICN 173744). 1-p. Butia yatay (Mart.) Becc. - 1. hábito; m. infrutescência; n. flor pistilada semi aberta; o. frutos; p. endocarpos (K. Soares et al. sn-HDCF 6214; K. Soares \& Callegaro 26). q. Butia odorata (Barb. Rodr.) Noblick - q. flor pistilada semi aberta para comparação (K. Soares 38). Figure 3 - a-f. Butia paraguayensis (Barb. Rodr.) L. H. Bailey - a. old palm habit; b. detail of the apex and middle part of the leaf and pseudopetiole; c. inflorescence; d. pistillate flower partially open; e. fruits; f. endocarps (K. Soares et al. 1). g-k. Butia witeckii K. Soares \& S. Longhi - g. habit; h. infructescence; i. pistillate flower partially open; j. fruits; k. endocarps (K. Soares et al. sn - ICN 173744). 1-p. Butia yatay (Mart.) Becc. - 1. habit; infructescence; n. pistillate flower partially open; o. fruits; p. endocarps (K. Soares et al. sn - HDCF 6214; K. Soares \& Callegaro 26). q. Butia odorata (Barb. Rodr.) Noblick - q. pistillate flower partially open to comparison (K. Soares 38). 
estaminadas 9-10 mm compr.; pistiladas 16-20 $\mathrm{mm}$ compr. Frutos amarelos ou verde amarelados quando maduros, 3,5-6,2 × 3,0-4,7 cm, pesando 22,8-57,1 g; mesocarpo muito fibroso; endocarpo ósseo, superfície quase lisa, 2,6-3,8 × 1,6-2,7 $\mathrm{cm}$, pesando $3,61-15,9 \mathrm{~g}$, provido de 3 quinas longitudinais e formato piramidal nos polos, especialmente no lado dos poros de germinação; sementes (1)-2-3, endosperma homogêneo. Eófilo simples.

Material selecionado: Quevedos, $2 \mathrm{~km}$ ao norte da Usina de Quebra Dentes, $29^{\circ} 22^{\prime} 07,17^{\prime \prime}$ 'S, $54^{\circ} 00^{\prime} 45,31^{\prime}$ 'W, fl. e fr., 24.III.2011, K. Soares et al. (ICN 173744).

Ocorre em uma pequena área que abrange os municípios de Quevedos, Júlio de Castilhos, São Pedro do Sul e São Martinho da Serra, geralmente ao longo do curso médio do Rio Toropi, onde está extremamente ameaçada. Espécie próxima de B. yatay e B. paraguayensis, no entanto é facilmente reconhecida em função do tamanho e peso dos seus frutos (extremamente fibrosos) e tamanho, peso e formato do endocarpo, sendo os maiores entre os Butia. O endocarpo dos frutos possui 3 quinas longitudinais e formato dos polos geralmente piramidal. Mesmo as infrutescências mais produtivas de $B$. witeckii apresentam, em geral, um número muito menor de frutos que o $B$. yatay, devido ao menor número de ráquilas na inflorescência e menor número de flores pistiladas por ráquila; apresenta também um número menor de pinas em cada lado da raque da folha. O porte médio dos indivíduos e o compr. da raque da inflorescência do $B$. witeckii é maior que o da espécie $B$. paraguayensis. Frutos maduros entre março e maio.

2.8 Butia yatay (Mart.) Becc. Agric. Colon. 10 (2): 498. 1916. Tipo: ARGENTINA, CORRIENTES: s. loc., s.d. (lectótipo, Martius, 1844, t. 30B!).

Figs. 31-p; $8 \mathrm{i}$

Estipe geralmente inclinado, 3,0-9,5 × 0,280,55 m. Folhas pinadas, 11-31 contemporâneas; bainha 120-150 × 9-16 cm; pseudopecíolo 40-130 cm compr., armado com fibras e dentes rígidos; raque $163-200 \mathrm{~cm}$ compr., com (57)-63-78 pinas de cada lado; pinas da parte mediana (58)-65-77 $\times$ 2-3 cm. Inflorescência interfoliar; pedúnculo 40$75 \times 1,5-2,2 \mathrm{~cm}$; profilo $34-65 \times 5-8 \mathrm{~cm}$; bráctea peduncular glauca, levemente estriada, 105-135 cm compr. total, parte expandida 40-110 × 7-14,3 $\mathrm{cm}$; eixo da inflorescência 50-90 cm compr.; raque $40-72 \mathrm{~cm}$ compr., com 68-155 ráquilas com
16-72 cm compr. Flores amarelas, esverdeadas ou arroxeadas; flores estaminadas 9-10 mm compr.; flores pistiladas $13-17 \mathrm{~mm}$ compr. Frutos amarelos, alaranjados, vermelhos ou purpúreos quando maduros, 2,7-4,2 × 1,5-3,8 cm, pesando 7,7-23,5 $\mathrm{g}$; mesocarpo pouco fibroso; endocarpo 1,8-2,8 $\times$ $1,0-1,6 \mathrm{~cm}$, pesando $1,2-3,5 \mathrm{~g}$; sementes, $1-3 \mathrm{com}$ endosperma homogêneo. Eófilo simples.

Material examinado: Chiapeta, na coxilha de campo com solo pedregoso, 13.XI.1985, f1., E. Franco (ICN 64360). Giruá, 6 km de Giruá, 1.II.1973, fr., B. Irgang \& J. Valls (ICN 21652). Giruá, Vale dos Butiazais, $22^{\circ} 02^{\prime} 58,1^{\prime \prime} \mathrm{S}, 54^{\circ} 19^{\prime} 26,3 \mathrm{~W}, 2 . \mathrm{V} .2012$, fl. fr., K. Soares \& R. Callegaro 26 (HDCF 6266). Quaraí, Coatepe/ Salamanca, 23.VIII.2004, fl., V.F. Knирp 2961 (ICN 132790). Quaraí, Coatepe, $30^{\circ} 24^{\prime} 13,9^{\prime \prime} \mathrm{S}$ e $56^{\circ} 11^{\prime} 00,1^{\prime \prime}$ W, 30.III.2011, fl. e fr., K. Soares et al. (HDCF 6214).

Espécie com larga distribuição natural na Argentina e Uruguai. Alguns trabalhos documentam sua ocorrência nestes países (Báez 1933; Chebataroff 1974; Crovetto \& Piccinini 1951). Na Região de Corrientes e Entre Rios (Argentina) pode alcançar $16 \mathrm{~m}$ alt. No Brasil a espécie ocorre somente no RS, em duas localidades, em Giruá, no Vale dos Butiazais (Mattos 1977), onde restam apenas algumas dezenas de indivíduos remanescentes do que foi um grande palmar, destruído nos anos 70 para ampliação de áreas agrícolas, e Quaraí, na região de Coatepe, onde ocupa uma área de aproximadamente $60 \mathrm{~km}^{2}$ (Marchiori \& Alves 2011). Citada também para o município de Chiapeta, segundo a coleta de $E$. Franco s.n. ICN 64360, onde provavelmente foi introduzida. Frequentemente cultivada na região das Missões.

3. Euterpe Mart., Hist. Nat. Palm. 2: 28 (1823), emend. 3: 165 (1837); 3: 230 (Ed 2) (1845). Tipo: E. oleracea Mart.

3.1 Euterpe edulis Mart. Hist. Nat. Palm. 2(2): 3334, t.32. 1824. Tipo: BRASIL. BAHIA: Almada, C. Martius s.n. (Isótipo, P!). $\quad$ Figs. $4 \mathrm{a}-\mathrm{d} ; 8 \mathrm{j}$

Estipe solitário, 3-15 $\times 0,1-0,2 \mathrm{~m}$, liso, com um palmito verde ou alaranjado formado pelas bainhas das folhas, com 1,0-1,5 m compr. Folhas pinadas, 8-15 contemporâneas, 1,3-2,5 m compr.; bainha 1-1,5 m; pecíolo $13-54 \mathrm{~cm}$ compr., com margem lisa, coberto com tomento escamoso achatado; raque 1,5-3 m compr., com 45-72 pares de pinas, distribuídas regularmente e num mesmo plano ao longo da raque, com as extremidades pendentes. Inflorescências infrafoliares, ramificadas ao nível de primeira 
ordem; bráctea peduncular papirácea, $50-80 \mathrm{~cm}$; ráquilas $45-110$, com $25-70 \mathrm{~cm}$ compr., cobertas por tricomas. Flores unissexuadas, ambas na mesma inflorescência; estaminadas 5-6 mm; pistiladas $3-4,5 \mathrm{~mm}$. Frutos globosos, 1-1,5 cm diâm., roxo-escuros ou pretos; mesocarpo fino, fibro-carnosos; endocarpo duro, 0,8-1,4cm diâm., com uma semente. Eófilo palmado.

Material selecionado: Novos Cabrais, 28.VIII.2012, fr., K. Soares \& L. Witeck 33 (HDCF 6271). São Leopoldo, 5.IX.1954, B. Rambo (PACA 2019). Torres, Lagoa Quadros, 5.IX.1954, fr., B. Rambo (PACA 45905). Vale do Sol, Linha XV de Novembro, I.1993, fl., J.A. Jarenkow \& D.B. Falkenberg 2290 (PEL 14038).

Espécie típica da formação Atlântica do sudeste e sul do Brasil, ocorrendo também na BA, GO, DF, MS, além da Argentina e Paraguai, em matas ciliares da bacia do Rio Paraná. No RS ocorre principalmente na Floresta Ombrófila Densa do litoral norte, entrando pela Depressão Central do estado; do litoral até o município de Novos Cabrais sua densidade populacional vai diminuindo visivelmente, aparece também no extremo norte do RS, na bacia do rio Uruguai. Em Linhares - ES e extremo sul da BA os espécimes são cespitosos, apresentando às vezes mais de 10 estipes. Está na lista de espécies ameaçadas do RS, na categoria "em perigo" (Consema 2003).

4. Geonoma Willd., Sp. Pl. 4 (1): 174, 593 (1805). Lectótipo: G. simplicifrons Willd.

4.1 Geonoma gamiova Barb. Rodr. Contr. Jard. Bot. Rio de Janeiro 6: t. 37. 1907; Suppl. Sert. Palm. Brasil. Tipo: Ilustração designada como lectótipo: BRASIL: SANTA CATARINA, Blumenau, Anon. sn. (not known). $\quad$ Figs. 4e-j; 8k

Estipe solitário ou cespitoso, profundamente anelado, 0,9-3,4 $\mathrm{m} \times 0,018-0,032 \mathrm{~m}$, anéis espaçados por $1,5-8,0 \mathrm{~cm}$, quando cespitosa produz poucos estipes. Folhas pinadas, 6-16 contemporâneas; bainha 17-30 × 6,0-8,8 cm; pecíolo $29-54 \times 0,5-0,9 \mathrm{~cm}$; raque $41-60 \mathrm{~cm}$ compr., com 3-11 pinas de cada lado, pode apresentar número diferente de pinas em cada lado, largura 1-11 cm, 0,4-3,0 cm de distância entre elas. Inflorescências interfoliares, podendo tornar-se infrafoliar no período de maturação dos frutos, ramificadas ao nível de segunda ordem, envolvidas por duas brácteas papiráceas, frisadas externamente, ambas caducas após a antese; profilo 14-20 × 1,5-3,5 cm; bráctea peduncular 13-18 $\times 1,5-3,5 \mathrm{~cm}$; pedúnculo $17-30 \times 0,9-1,5 \mathrm{~cm}$; raque da inflorescência 7-19 × 0,5-0,6 cm, com 5-28 ráquilas, as basais geralmente ramificadas; ráquilas $12-45 \times 0,3-0,4 \mathrm{~cm}$. Alvéolos florais dispostos espiraladamente ao redor das ráquilas. Flores, estaminadas $4 \mathrm{~mm}$ compr.; pistiladas ca. 3 $\mathrm{mm}$ compr. Frutos ovóides 1,0-1,5 × 0,7-1,2 cm, pretos quando maduro; endocarpo com superfície lisa, $0,5-1,2 \mathrm{~cm}$ diâm, marrom-avermelhado, com uma semente, endosperma homogêneo. Eófilo bífido. Material examinado: Alto Feliz, para Caí, 6.III.1933, fl., B. Rambo (PACA 241). Maquiné, Estação Experimental Fitotécnica, 7.VII.1980; fr., J. Mattos \& N. Mattos 21875 (HAS 67404). Montenegro, 5.IX.1954, fr., B. Rambo (PACA 47141). Morrinhos do Sul, 13.I.1995, fr., J.A. Jarenkow \& C.F. Widholzer 2546 (PEL 14294). Osório, 18.V.1972, fr., J. Valls \& B. Irgang (ICN 9937). Dom Pedro de Alcântara, 3.I.2000, C. Jurinitz 18 (ICN 120598). Riozinho, próximo ao Pico da Canastra, 28.VIII.2012, fl. e fr., K. Soares \& H. Büneker 34 (HDCF 6272). Torres, 4.I.1988, fl., J. Waechter 2289 (ICN 83666). Três Cachoeiras, 9.I.1992, fl., R. Záchia 726 (ICN 119312).

Ocorre desde o RJ até o RS, na floresta Atlântica. No estado do RS aparece principalmente entre os municípios de Torres a Osório, ocorrendo também, de forma descontínua e rara, na Encosta inferior do Nordeste e extremo leste da Depressão Central. Saraiva et al. (2012) citam sua ocorrência para o município de Pelotas, estando também incluída na lei $\mathrm{N}^{\circ} 4.119$ deste município (flora nativa de ocorrência regional consideradas ameaçadas de extinção), no entanto somente a espécie G. schottiana pode ser confirmada para este município, possivelmente houve confusão na sua identificação, pois as folhas dos indivíduos jovens de G. schottiana possuem pinas mais largas como às da G. gamiova. Está na lista de espécies ameaçadas do RS, na categoria "criticamente ameaçada" (Consema, 2003). Lorenzi (2010) descreveu a espécie G. meridionalis Lorenzi, alegando que o binômio G. gamiova seria um nome nudum, por não possuir uma obra princeps com sua descrição, bem como, uma exsicata tipo. Já Henderson (2011), na sua revisão sobre o gênero, desconsiderou totalmente G. gamiova e todas as outras espécies que não possuíam material tipo em herbários, colocando G. meridionalis como sinônimo de G. pohliana Mart. No presente trabalho considera-se o binômio $G$. gamiova como válido até que mais estudos sejam realizados, uma vez que, na ausência de material tipo em herbário, a ilustração pode ser considerada o tipo (McNeill et al. 2012), presente no protótipo, Tab. XXXVII (Barbosa Rodrigues 1907). 

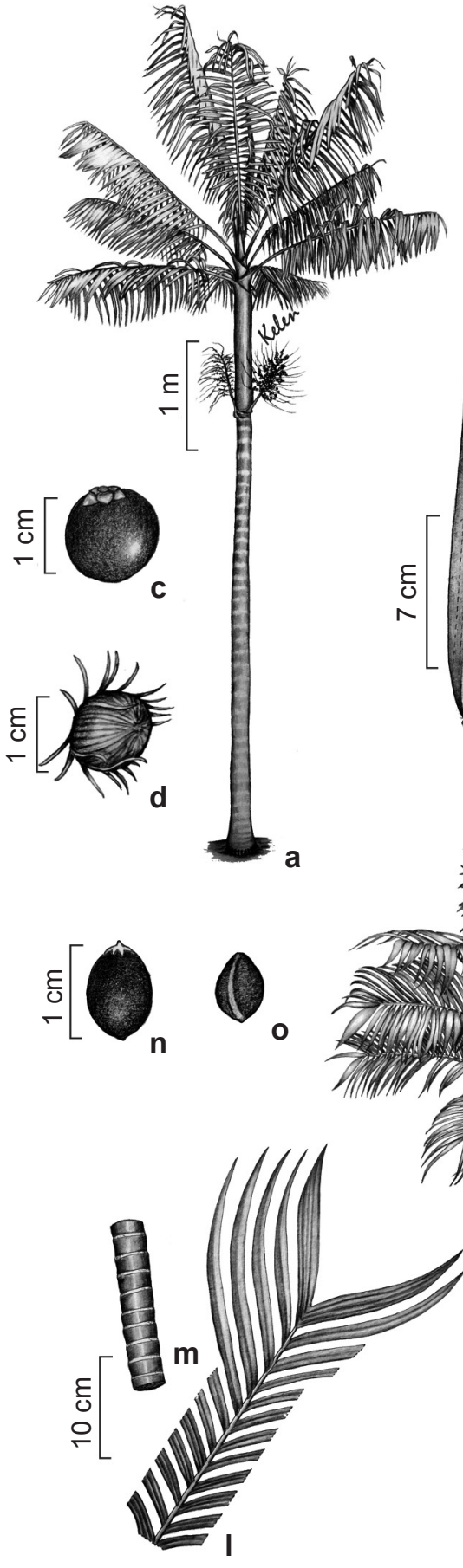
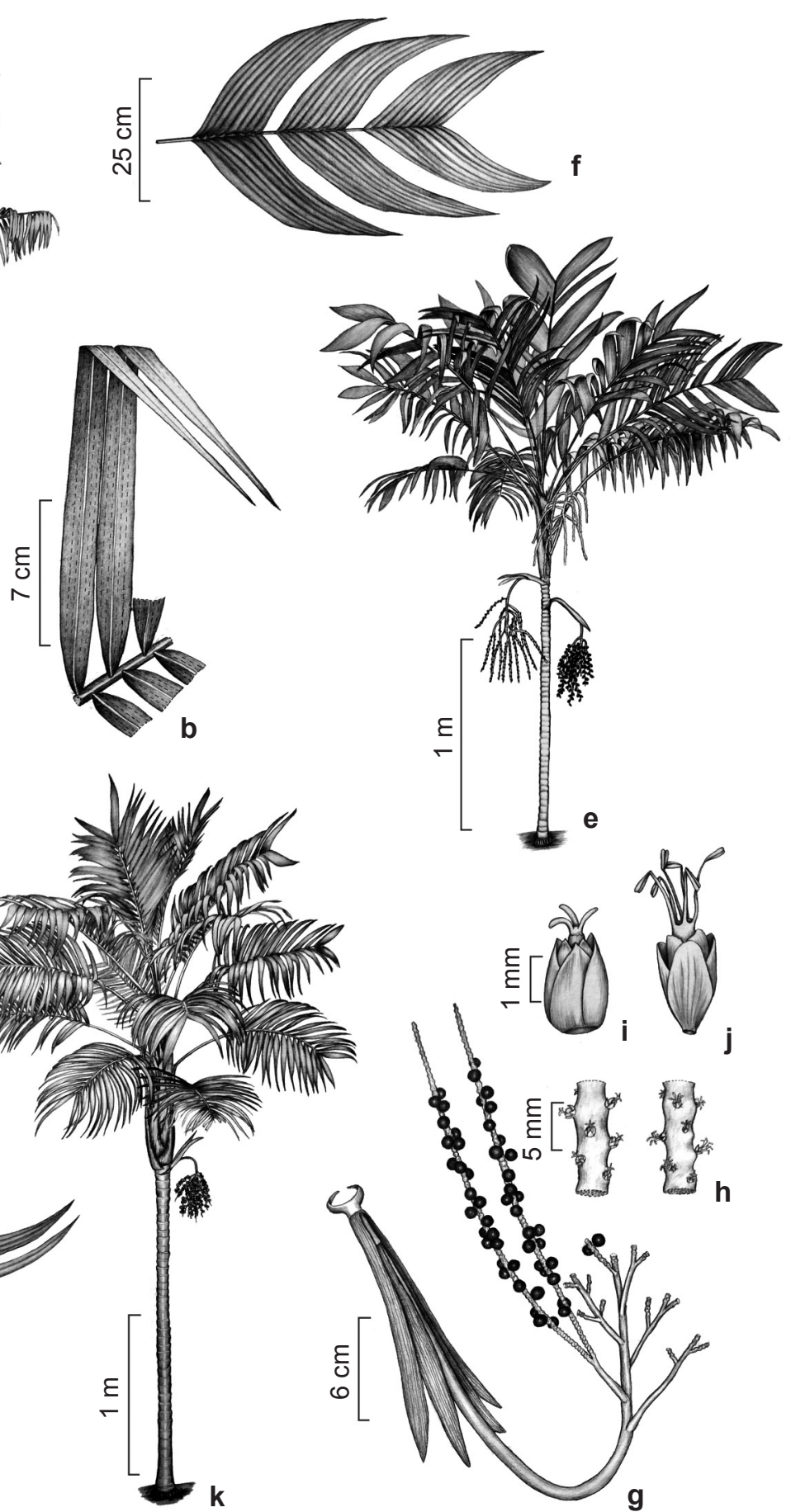

Figura 4 - a-d. Euterpe edulis Mart. - a. hábito; b. detalhe da folha; c. fruto; d. endocarpo (K. Soares \& Witeck, 33). e-j. Geonoma gamiova Barb. Rodr. - e. hábito; f. folha; g. infrutescência; h. ráquilas com flores pistiladas e estaminadas; i. flor pistilada; j. flor estaminada (K. Soares \& Büneker 34). k-o. Geonoma schottiana Mart. - k. hábito; 1. folha; $m$. detalhe do estipe; $n$. fruto; o. endocarpo (K. Soares 36$)$.

Figure 4 - a-d. Euterpe edulis Mart. - a. habit; b. leaf detail; c. fruit; d. endocarp (K. Soares \& Witeck, 33). e-j. Geonoma gamiova Barb. Rodr. - e. habit; f. leaf; g. infuctescence; h. rachillae with pistillate and staminate flowers; i. pistillate flower; j. staminate flower ( $K$. Soares \& Büneker 34). k-o. Geonoma schottiana Mart. - k. habit; 1. leaf; m. stem detail; n. fruit; o. endocarp (K. Soares 36). 
4.2 Geonoma schottiana Mart. Hist. Nat. Palm. 2: 143 , t. 11 A. 1826 . Tipo: BRASIL. RIO DE JANEIRO: s.d., H. Schott 4111 (Holótipo, M, n.v.). Figs. 4k-o; 81

Estipe solitário, anelado, 1,5-5,0 × 0,017$0,04 \mathrm{~m}$, anéis distantes entre si por $1,5-8,0 \mathrm{~cm}$. Folhas pinadas, 7-24 contemporâneas; bainhas $23-33 \times 6,0-12 \mathrm{~cm}$; pecíolo $30-87 \times 0,5-1,2$ $\mathrm{cm}$; raque $44-130 \mathrm{~cm}$ compr., com 11-40 pinas estreitas, distribuídas regularmente ao longo da raque, em um plano e com largura mais ou menos uniforme, exceto em indivíduos jovens, que podem apresentar pinas com larguras variadas; pinas com uma nervura central e duas laterais, 13-60 $\times 0,5-3,0 \mathrm{~cm}$, as da parte apical da folha até 10 $\mathrm{cm}$ larg. Inflorescências interfoliares, podendo tonar-se infrafoliares no período de maturação dos frutos, ramificadas ao nível de segunda ou terceira ordem, envolvidas por duas brácteas papiráceas, caducas após a antese; profilo $16-36 \times 1,8-4,0$ $\mathrm{cm}$; bráctea peduncular $10-31 \times 1,8-4,0 \mathrm{~cm}$; pedúnculo $20-60 \times 1-2 \mathrm{~cm}$; raque da inflorescência $15-22 \mathrm{~cm}$ compr., com 12-60 ráquilas de 8-32 × $0,3-0,4 \mathrm{~cm}$, as basais ramificadas. Alvéolos florais dispostos espiraladamente ao redor das ráquilas. Flores; estaminadas $4 \mathrm{~mm}$ compr.; pistiladas ca. $3 \mathrm{~mm}$ compr. Frutos globosos, $0,8-1,3 \times$ $0,6-1,2 \mathrm{~cm}$, pretos quando maduros; endocarpo 0,6-1,5cm diâm., superfície lisa com uma semente; endosperma homogêneo. Eófilo bífido.

Material examinado: Alto Feliz, para Caí, 6.III.1944, fl., B. Rambo (PACA 34032). Dom Pedro de Alcântara, 4.I.2000, C. Junrinitz 26 (ICN 120605). Guaíba, 22.IV.2006, L. Lima 319 (ICN 144129). Maquiné, Reserva Biológica da Serra Geral, 5.XI.2003, fr., M.L. Abruzzi 5215 (HAS 44923). Mostardas, estrada para o balneário, 14.II.1991, fl. e fr., J.A. Jarenkow 1842 (PEL 12303). Osório, condomínio Jardim Lagoa, 21.Y.1992, fr., N. Silveira 10842 (HAS 67414). Pelotas, Praia do Laranjal, localidade de Barro Duro, 31.VIII.2012, fr., K. Soares 36 (HDCF 6274). Pelotas, Barro Duro, xx.III.1989, fl. e fr., J.A. Jarenkow 1270 (PEL 11337). Porto Alegre, 26.IX.2004, fr., R. Setubal 399 (ICN 155292). Pelotas, 17.III. 1989, fl., J. Jarenkow 1270 (ICN 11337). Portão, para São Leopoldo, 5.VI.1935, B. Rambo (PACA 2090). Rio Grande, próx. À Quinta, 28.XI.1986, f1., J.A. Jarenkow \& B. Irgang 530 (PEL 9345). Rio Grande, Quinta, 23.IV.1988, f1., J. Waechter 2315 (HAS 28356). Tapes, 27.IX.1975, fl., L. Baptista \& M.L. Porto (HAS 786; ICN 29453). São Leopoldo, 28.VI.1949, fl., B. Rambo (PACA 42217). Torres, 6.IX.2005, fr., R.M. Senna et al. 942 (HAS 43729). Tramandaí, 19.III.1976, L. Baptista et al. (ICN 31050). Três Cachoeiras, 9.I.1992, fl., R. Záchia 729 (ICN119311).
Espécie com ampla distribuição no Brasil (MG, ES, RJ, SP, e litoral do PR, SC e RS) em florestas costeiras planas, de encostas, restingas e capoeirões, bem como em matas ciliares da região Sudeste, desde o nível do mar até $1.600 \mathrm{~m}$ de altitude (Lorenzi 2010). No RS aparece na região litorânea, desde os municípios de Torres até o município de Rio Grande. Está na lista de espécies ameaçadas do RS, na categoria "criticamente ameaçada" (Consema 2003).

5. Syagrus Mart., Palm. fam. 18 (1824). Tipo: $S$. cocoides Mart.

5.1 Syagrus romanzoffiana (Cham.) Glassman, Fieldiana, Bot. 31: 382, 1968. Tipo: BRASIL. SANTA CATARINA, s.d., L.K.A. Von Chamarisso s.n. (Holótipo, LE, destruído; lectótipo, Chamisso, 1822, t. 5-6, n.v.).

Figs. 5a-f; $8 \mathrm{~m}$

Estipe solitário, 4-20 × 0,2-0,55 m. Folhas pinadas, 7-25 contemporâneas; pseudopecíolo com margens fibrosa, 1,0-1,7 m compr.; pecíolo até 10 cm compr.; raque 1,7-4,4 m compr. (inicialmente acanalada adaxialmente, tornando-se aguda na extremidade), com 150-250 pinas de cada lado; pinas dispostas irregularmente ao longo da raque em grupos de 2-7, inseridas em vários ângulos, conferindo à folha um aspecto plumoso, as da parte mediana da raque $60-100 \times 1,5-4,5 \mathrm{~cm}$. Inflorescência interfoliar, até $1,5 \mathrm{~m}$ compr.; pedúnculo $50-75 \mathrm{~cm}$ compr.; profilo $30-60 \mathrm{~cm}$ compr.; bráctea peduncular profundamente frisada (sulcada) longitudinalmente, 100-223 cm compr. total, parte expandida 70-164 × 10-28 cm; raque da inflorescência 30-110 cm compr., com 40-330 ráquilasde $15-77 \mathrm{~cm}$ compr. Flores amarelas ou cremes; estaminadas $10 \mathrm{~mm}$ compr.; pistiladas 5-6 $\mathrm{mm}$ compr. Fruto amarelo ou alaranjado, ovóide, alongados ou quase redondos, $1,8-3,5 \times 1,4-2,8$ $\mathrm{cm}$; mesocarpo mucilaginoso; endocarpo $1,5-2,5$ $\times 1,2-2,0 \mathrm{~cm}$; endosperma irregular (giboso).

Material selecionado: Canguçu, Localidade Florida, 30.VIII.2012. fl. e fr., K. Soares 35 (HDCF 6273).

Ocorre no Uruguai, Argentina, Paraguai e Brasil (sudeste da BA, GO, DF, MG, MS, SP, RJ, ES, PR, SC e RS). Cresce nas matas, mas pode comportar-se como planta pioneira (Reitz 1974). No RS a espécie é rara apenas nos "campos de cima da serra" e na Floresta Ombrófila Mista do nordeste gaúcho; na província do Espinal e região do Taim está confinada aos cursos d'água. É a palmeira mais utilizada no paisagismo do sul do Brasil (Lorenzi et al. 2004); seu fruto é um recurso 


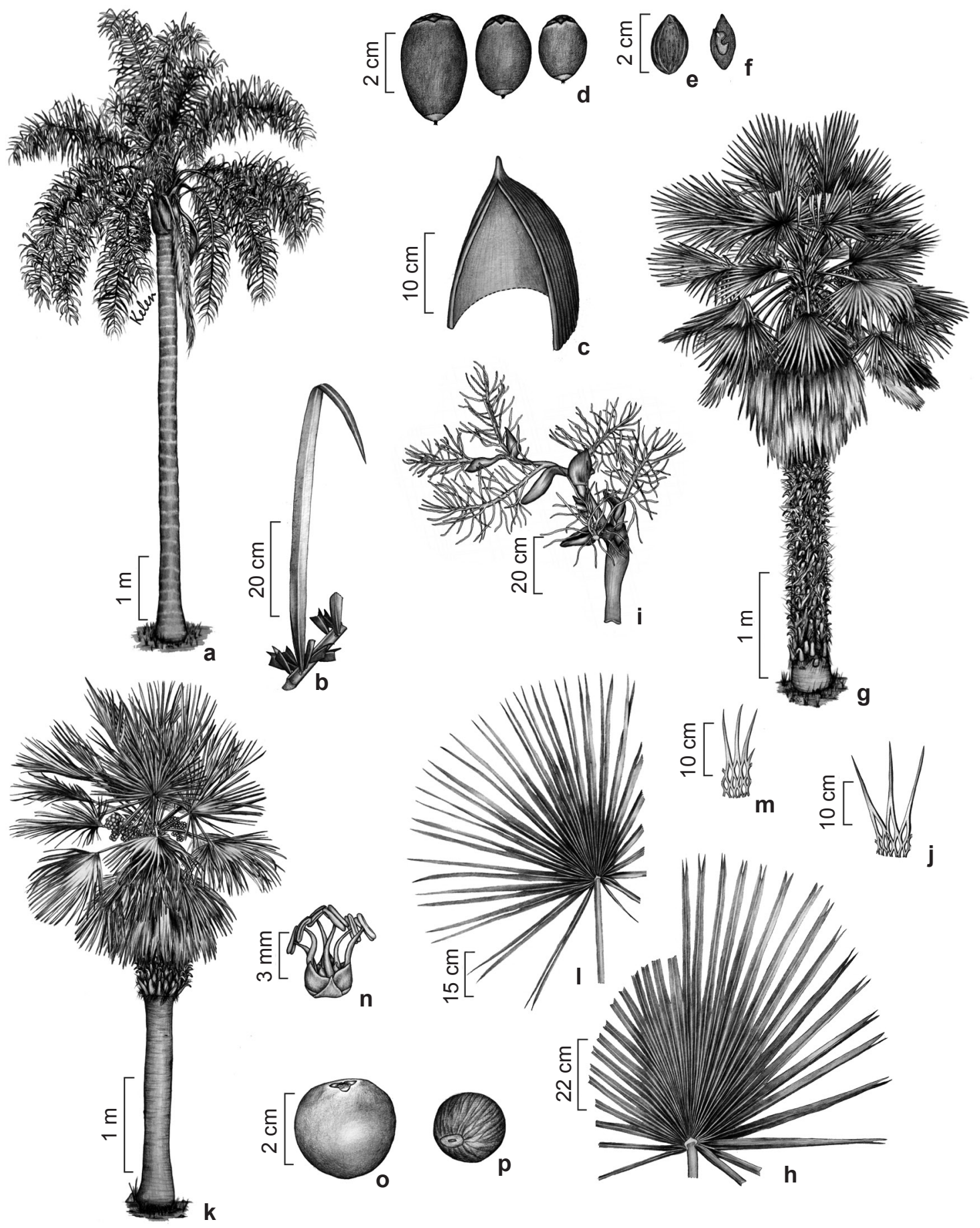

Figura 5 - a-f. Syagrus romanzoffiana (Cham.) Glassman. - a. hábito; b. detalhe da folha com inserção das pinas; c. detalhe da espata sulcada; d. frutos; e. endocarpo; f. endocarpo partido mostrando endosperma giboso (K. Soares 35). g-j. Trithrinax acanthocoma Drude - g. hábito; h. folha; i. inflorescência; j. espinhos da bainha (K. Soares 31). k-p. Trithrinax brasiliensis Mart. - k. hábito; 1. folha; m. espinhos da bainha; n. flor hermafrodita; o. fruto; p. endocarpo (K. Soares et al. 23).

Figure 5 - a-f. Syagrus romanzoffiana (Cham.) Glassman. - a. habit; b. leaf detail with leatlets insertion; c. detail of the grooved peduncular bract; d. fruits; e. endocarp; f. endocarp endview showing gibbous endosperm (K. Soares 35). g-j. Trithrinax acanthocoma Drude - g. habit; h. leaf; i. inflorescence; j. spiny of leaf sheaths (K. Soares 31 ). k-p. Trithrinax brasiliensis Mart. $-\mathrm{k}$. habit; 1. leaf; m. spiny of leaf sheaths; n. hermaphrodict flower; o. fruit; p. endocarp (K. Soares et al. 23). 
importante para inúmeras espécies da fauna nativa (Carvalho 2006). Apresenta uma grande variedade morfológica e muitos nomes populares: jerivá, coqueiro, coco-babão, licuri, coco-de-cachorro, queen-palm, entre outros.

6. Trithrinax Mart., Hist. Nat. Palm. 2: 149 (1837). Tipo: T. brasiliensis Mart.

6.1 Trithrinax acanthocoma Drude, Gartenflora 27: 361, 1878. Tipo: BRASIL. RIO GRANDE DO SUL, s.d., A.F.M. Glaziou 9014 (holótipo, C!).

Figs. $5 \mathrm{~g}-\mathrm{j} ; 8 \mathrm{n}$

Palmeira monoica; estipe solitário, 1,5-13 $\times$ $0,17-0,35 \mathrm{~m}$, recoberto pelas bainhas das folhas já caídas e por uma rede de fibras muito rígidas, dispostas oblíquas e entrecruzadas, engrossadas na parte superior e terminadas em agulhões lignosos, persistentes, rígidos, $12-25 \mathrm{~cm}$ compr. Folhas palmado-flabeliformes, 15-51 contemporâneas, verde escuras na parte de cima e cobertas por indumento esbranquiçado na parte de baixo; bainha $16-26 \mathrm{~cm}$ compr., com um reforço central e espinhos de 12-25 cm compr., rígidos e longo persistente; pecíolo $64-90 \times 3-4 \mathrm{~cm}$, rígido, pouco flexível, exceto pela curvatura próxima da bainha, margem lisa e afiada, espessura constante, terminado em uma hástula córnea triangular; 32-43 segmentos (pinas), 80-103 × 4,5-6 cm, plissados e partindo de um ponto comum, os maiores na parte central, diminuindo de tamanho e largura conforme sua disposição segue lateralmente, todos os segmentos são unidos, separando-se então pela metade do seu compr. (50-56 cm finais) e terminados em uma ponta dupla pungente, fendida até $1 / 5$ do compr. total (6-16 cm a partir da ponta). Inflorescência interfoliar ramificada ao nível de terceira ordem, 6-7 ramificações principais de $30-50 \mathrm{~cm}$ compr.; pedúnculo recurvado em " $\mathrm{S}$ ", $40-90 \times 2,5-4,0 \mathrm{~cm} ; 6-7$ brácteas pedunculares (uma para cada ramificação), $17-26 \times 9-16 \mathrm{~cm}$, parte expandida $13-18 \mathrm{~cm}$ compr.; profilo $30-38$ $\times 6-9 \mathrm{~cm} ; 34-50$ ráquilas por segmento, $6-16 \mathrm{~cm}$ compr. Frutos globosos, amarelo-esbranquiçados quando maduros, 2,0-3,0 cm diâm.; mesocarpo carnoso que se destaca facilmente do endocarpo com uma única semente. Eófilo simples.

Material examinado: Caxias do Sul, em direção à São Marcos, km 148, localidade Pedras Brancas, 28.V.1971, Mattos 15616 (SP). Farroupilha, 2920'4.6'S, 4943'23.2”W, 4.IV.2001, Rossato 17 (NY). Giruá, Rincão Maciel, 25.III.77, RGS 311 (HAS 4331). Nonoai, Reserva do Parque Estadual, 23.IV.1986, A. Benetti et al. (HAS 4599). Nova Prata, cultivada, 26.VIII.2012, K. Soares 31 (HDCF 6269). Nova Petrópolis, Linha Brasil, Pedras do Silêncio, 24.IV.2006, Cossio et al. 67 (ICN). Torres, Parque Itapeva, 28.VI.1985, J. Waechter \& L. Baptista 2102 (ICN 62890). Vacaria, vale do Rio Ibiri, J.C. \& F. Lindeman (ICN 9490). Fazenda Cedro, 12.IV.1975, fl., R. Wasum (PACA 109178).

Erroneamente identificada em trabalhos científicos e coleções botânicas como T. brasiliensis (Sühs \& Putzke 2010, Carvalho 2010). A espécie T. acanthocoma ocorre naturalmente nos três estados sulinos do Brasil e no Paraguai, em populações geralmente com poucos indivíduos; é característica da Floresta Ombrófila Mista; como um elemento estranho aparece na região do Morro dos Conventos, em zona da mata pluvial da encosta Atlântida em Araranguá - SC (Reitz 1974), bem como em Torres, no Parque Estadual de Itapeva. No RS a espécie ocorre em altitudes superiores aos $450 \mathrm{~m}$, nos municípios da serra do nordeste, no Vale do Rio Pardo (Sühs \& Putzke 2010), Cruz Alta (Mattos 1977), Giruá (segundo a coleta $R G S 311$ - HAS 4331) e provavelmente em outros municípios do Planalto gaúcho. É a espécie do gênero com mais rápido desenvolvimento vegetativo.

Por muitos anos a espécie $T$. brasiliensis, citada para os campos do RS, representou o gênero. Em 1878, Drude descreveu para o mesmo estado T. acanthocoma; no ano seguinte outra espécie, achada na Argentina e inicialmente batizada como Copernicia campestris Burmeist., foi renomeada por Drude e Grisebach como T. campestris. Drude (1882) considerou também como uma espécie distinta a planta achada por Martius (1844) na Bolívia e figurada no seu Palmetum Orbignyanum como T. brasiliensis, the dando o nome de $T$. schyzophylla, cuja descrição é encontrada na Flora Brasiliensis. A última espécie, T. biflabellata foi descrita por Barbosa Rodrigues (1899). Atualmente duas dessas espécies (que ocorrem no Brasil: T. acanthocoma e T. biflabellata) encontramse erroneamente sinonimizadas (Mattos 1977; Henderson et al. 1995; Carvalho 2010). Mattos (1977) citou para o RS apenas uma espécie com duas variedades (var. acanthocoma e var. brasiliensis), no entanto, segundo o local do material estudado, o nome dado às variedades está trocado, neste trabalho o autor comenta que $T$. brasiliensis é "mais ou menos entouceirada", fato que não caracteriza ambas as espécies gaúchas; esta confusão deve-se provavelmente à descrição de Martius, que no seu Palmetum Orgygnianum havia reconhecido $T$. 
schyzophylla (entouceirada, encontrada na Bolívia e extremo norte da Argentina) como T. brasiliensis. Já Pingitore (1978) reconheceu as 5 espécies. Lorenzi et al. (2010) reconheceu 3 espécies como nativas do Brasil, no entanto a $T$. schyzophylla apresentada na obra é na verdade $T$. biflabellata Barb. Rodr. (a única que ocorre no MS).

6.2 Trithrinax brasiliensis Mart., Hist. Nat. Palm. 2: 150. 1837. Tipo: BRASIL. RIO GRANDE DO SUL, s. loc. s.d., F. Sellow s.n. (Holótipo, M!).

Figs. 5k-p; 80

Estipe solitário, ereto ou inclinado, 1-6 $\times 0,2-0,3 \mathrm{~m}$, recoberto pelos remanescentes das bainhas espinescente e fibrosa das folhas já caídas, tornando-se nu com a idade ou pela ação do fogo; Folhas palmado-flabeliformes, 10-55 contemporâneas, 1,0-1,8 cm compr., verde-oliva na parte de cima e glauco-grisáceas em baixo; bainhas $17-23 \mathrm{~cm}$ compr., com uma rede de fibras dispostas oblíquas e entrecruzadas, engrossadas na parte de cima e terminadas em espinhos de 6-10-(14) cm compr., decíduos após a morte das folhas, enquanto as bainhas são mais persistentes; pecíolo 46-55 × 2,0-2,5 cm, com uma hástula córnea triangular; 20-38 segmentos (pinas), cada um ca. 40-75 $\times$ $1,5-4,0 \mathrm{~cm}$, plissados, os maiores na parte central da folha; segmentos bifurcados, ca. 1/2 do compr. total (últimos $17-35 \mathrm{~cm}$ ), ponta dupla flexível. Inflorescência ramificada ao nível de terceira ordem, 6-7 ramificações principais; pedúnculo recurvado em "S", 65-69 × $3 \mathrm{~cm}$; 6-7 brácteas pedunculares, $18-26 \mathrm{~cm}$ compr. total, $13-18 \times 7-15$ $\mathrm{cm}$ de parte expandida; profilo $22-25 \times 7-9 \mathrm{~cm}$; $35-74$ ráquilas, as da base geralmente ramificadas. Frutos globosos, 2,2-3,2 cm diâm.; mesocarpo carnoso destaca-se facilmente do endocarpo com uma única semente. Eófilo simples.

Material examinado: Bagé, estrada geribá km. 83, 9.X.1976, fl., Adelino \& B. Irgang 11 (ICN34145); Casa de Pedra, 3.I.2006, fr., R. Cossio 61 (ICN143748). Caçapava do Sul, Guaritas, 3050'06.4'S 5330'37'W, 7.VII.2012, fl., fr., K. Soares; L. Witeck \& H. Bünecker 23

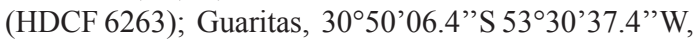
249 m, 18.II.2011, Reis et al. 2611 (HBR). Cachoeira do Sul, 4.V.1975, fl., R. Wasum (PACA 109179). Canguçu, UTM 3676806576642 , 11.XII.1999, fr., Salazar \& Ferrer (ICN116565). Julio de Castilhos, próximo ao Rio Toropi, $29^{\circ} 23^{\prime} 41.3^{\prime}$ 'S, 5401'19.9”'W 286 m, 17.II.2011, Reis et al. 2607 (HBR). Lavras do Sul, Rincão do Inferno, 17.IX.1958, fl., B. Rambo (PACA 63567). Quevedos, próximo ao Rio Toropi, $29^{\circ} 23^{\prime} 41.3^{\prime}$ 'S, $54^{\circ} 01$ ' $19.9^{\prime \prime} \mathrm{W}$ 286 m, 17.II.2011, Reis et al. 2607 (HBR). Santa Maria,
Localidade Santo Antão, 29³7’35.6”'S 5351'42.9”'W, 19.II.2011, Reis et al. 2613 (HBR). São Martinho da Serra, 292 $28^{\prime} 04,1^{\prime \prime}$ 'S 5403'26,0”W, 14.III.2013, fr., $K$. Soares et al. 45 (HDCF).

Palmeira muito rara e ameaçada pelo gado, que impede sua regeneração, e pelo fogo (Lorenzi et al. 2010); ocorre no centro e sul do RS, sempre em altitudes inferiores a $450 \mathrm{~m}$, também no departamento de Treinta y Tres, no Uruguai (Lombardo 1964); cresce nos campos sujos, em borda de matas ciliares e nos cerros, sempre associada às rochas, em relevos inclinados e com grande exposição solar, onde forma populações pequenas, sendo os municípios de Julio de Castilhos, São Pedro do Sul e São Martinho da Serra os locais com as maiores concentrações (29'27'15,6'S, $54^{\circ} 03^{\prime} 12,3^{\prime \prime} \mathrm{W}$ e $29^{\circ} 22^{\prime} 54,89^{\prime} \mathrm{S}, 54^{\circ} 01^{\prime} 14,35^{\prime \prime} \mathrm{W}$ ), onde divide espaço com a espécie Butia witeckii $\mathrm{K}$. Soares \& S. Longhi. Palmeira associada a outras plantas de caráter xerotérmico (relictos de eras mais secas e frias do Pleistoceno), como Cactaceae, Bromeliaceae do gênero Dyckia, Myrtaceae anãs e espécies arbóreo-arbustivas pioneiras. A espécie tratada como T. brasiliensis em muitos trabalhos acadêmicos, jardins Botânicos, jardins públicos e privados é, na verdade, T. acanthocoma. Está na lista de espécies ameaçadas do RS, na categoria "em perigo" (Consema 2003). Incluída também na lista da IUCN na categoria "informações não disponíveis" (IUCN 2012).

\section{Espécies excluídas da flora do Rio Grande do Sul}

7.1 Acrocomia aculeata (Jacq.) Lodd. ex Mart. Hist. Nat. Palm. 3(8): 286. 1845. Tipo: MARTINIQUE, t. 169, 1763 (Lectótipo, Glassman, 1972, n.v.).

Fig. 6a-d

Material selecionado: BRASIL. MINAS GERAIS: Morro do Pilar, na MG 10, 23k0658508, 7874219, 22.VIII.2012, fr., K. Soares \& L. Assis 28 (HDCF).

Descrita em 1763 como Cocos aculeata Jacq. à partir de indivíduos nativos da Martinica, no Caribe (Jacquin 1763), a espécie logo foi transferida para o gênero Acrocomia e ganhou incontáveis sinonímias (Henderson et al. 1995; Lorenzi et al. 2010), devido a sua ampla variação morfológica e distribuição geográfica, que vai desde o México até o extremo norte do PR, sendo especialmente comum nas Regiões Sudeste e Centro-Oeste do Brasil (MG, SP, GO e MT); para alguns botânicos as populações que ocorrem no Pantanal, Paraguai e Argentina (A. totai Mart.) e litoral do Nordeste ( $A$. intumescens Drude) são a mesma espécie, apesar 


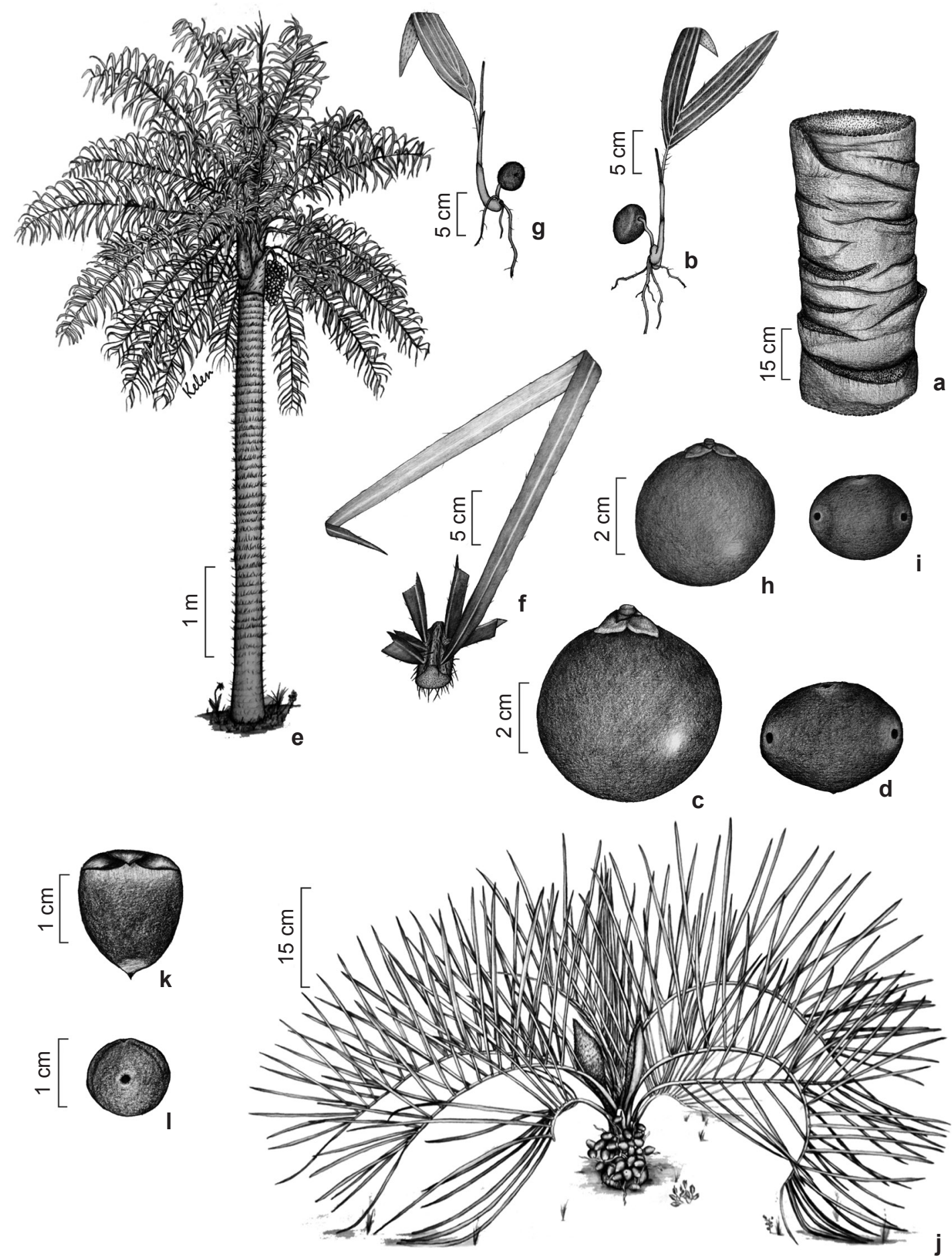

Figura 6 - a-d. Acrocomia aculeata (Jacq.) Lodd. Ex Mart. - a. detalhe do estipe; b. eófilo da plântula; c. fruto; d. endocarpo (K. Soares \& Assis 28). e-i. Acrocomia totai Mart. - e. hábito; f. detalhe da folha; g. eófilo da plântula; h. fruto; i. endocarpo (K. Soares et al. 27). j-1. Butia microspadix Burret-j. hábito; k. fruto; 1. endocarpo (K. Soares \& Flores 8). Figure 6 - a-d. Acrocomia aculeata (Jacq.) Lodd. Ex Mart. - a. stem detail; b. eophyll; c. fruit; d. endocarp (K. Soares \& Assis 28). e-i. Acrocomia totai Mart. - e. habit; f. leaf detail; g. eophyll; h. fruit; i. endocarp (K. Soares et al. 27). j-1. Butia microspadix Burret - j. habit; k. fruit; 1. endocarp (K. Soares \& Flores 8$)$. 
de todas diferenças morfológicas; de fato, em regiões limites entre a ocorrência destas espécies são encontrados exemplares com características em comum (oeste de SP, MS, PA, BA, ES, $\mathrm{RJ}$ ); uma análise genética seria necessária para confirmar a separação ou união dos táxons, bem como, investigar os indivíduos provenientes da Ilha Martinica, uma vez que o táxon do Brasil central foi nomeado como A. sclerocarpa Mart. Devido às características morfológicas marcantes, consideram-se neste artigo as três espécies como válidas.

Acrocomia aculeata é citada por Sobral et al. (2006) para a Região das Missões e Campanha do RS, com base na localização de indivíduos da espécie $A$. totai próximos à São Borja - RS. Já a fotografia da planta, que aparece na obra "Flora arbórea e arborescente do Rio Grande do Sul", realmente trata de duas A. aculeata cultivadas em jardim residencial, mas que provavelmente foi fotografadas em outro estado. Os autores do presente artigo não confirmam a presença de populações naturais de nenhuma espécie deste gênero no RS. Quanto à espécie $A$. aculeata, apenas três indivíduos adulto foram localizados no estado, um em Santa Maria (em jardim residencial), um no Parque Witeck em Novos Cabrais e outro próximo à Passo Fundo-RS, todos exemplares trazidos ainda jovens de outros estados brasileiros.

7.2 Acrocomia totai Mart., Voy. Amér. Mer. 7(3): 78-81, pl. 9, f. 1, pl. 29b. 1844. Tipo: ARGENTINA, CORRIENTES: s.d., A. D. d'Orbigny 4 (Holótipo $\mathrm{P}, n . v$. , fragmento do tipo e foto, $\mathrm{BH}, n . v$.)

Fig. 6e-i

Material selecionado: BRASIL. RIO GRANDE DO SUL: Jaguarí, cultivado na margem da estrada, $29^{\circ} 30^{\prime} 20,4^{\prime \prime} \mathrm{S} 54^{\circ} 40^{\prime} 29,49^{\prime \prime} \mathrm{W}, 3 . \mathrm{VIII} .2012$, fr., K. Soares et al. 27 (HDCF).

O gênero Acrocomia, assim como Butia, é frequentemente disperso, ao longo das estradas e ferrovias, pelo homem e pelos animais (Soares \& Witeck 2009; Soares 2013). Lorenzi et al. (2010) citam esta espécie para o estado, pois comumente são encontrados indivíduos ao longo das rodovias ou cultivados em jardins particulares e públicos (Santa Maria, na BR 392 e Rua Visconde de Pelotas; Entre Ijuis, na praça central; Jaguari; São Borja, etc), no entanto, todas estas palmeiras foram trazidas de outros estados do Brasil e da Argentina, fato confirmado pelos proprietários das áreas; eventualmente frutos destes indivíduos acabam sendo dispersos. Como não foram encontradas populações desta espécie pelos autores do presente artigo, concluí-se que ela não ocorre naturalmente no estado.

8. Butia microspadix Burret, Notizbl. Bot. Gart. Berlin-Dahlem 10: 1050. 1930. Tipo: BRAZIL, s. loc., provavelmente SP, s.d., F. Sellow s.n. (holótipo: B, destruído, Lectotipo, SP, 12267!).

Fig. $6 \mathrm{j}-1$

Material selecionado: BRASIL. PARANÁ: Ponta Grossa, Represa Alagados - Usina Hidroelétrica São Jorge/Ponta Grossa, 2.III.2010, fr., K. Soares \& T.B. Flores 8 (HDCF 6232). Ponta Grossa, fazenda de criação, fr., 6.II.1946, Swallen (PEL 8490).

Trata-se de uma palmeira rara, que ocorre somente no sul de SP e no PR, nos "Campos Gerais". Glassman (1979), Lorenzi et al. (2004) e Noblick (2010) citam esta espécie para o RS baseados na coleta de Luederwaldt s.n. (SP 12267) que indica "Rio Grande do Sul" como local. Este material herborizado (assim como inúmeras outras exsicatas) proveio do antigo Herbário do Museu Paulista (atual Museu do Ipiranga) e, ao ser incorporado no Herbário do Instituto de Botânica do estado de são Paulo (SP), teve sua etiqueta refeita, por não encontrar-se em bom estado (segundo a curadora do herbário SP: Maria Mamede, comunicação pessoal). A espécie nunca foi encontrada no RS e trata-se provavelmente de um erro de informação na etiqueta; além disso, segundo a curadora Maria Mamede (Comunicação pessoal), Luederwaldt realizou muitas coletas botânicas na região Sul do estado de São Paulo, mas não há informações de que ele tenha expedicionado pelo RS.

\section{Espécies consideradas sinonímias}

9. Butia missionera Deble \& Marchiori, Balduinia 30: 5. 2011. Tipo: BRASIL. RIO GRANDE DO SUL: Giruá, Campo do Butiá, 22.XII.2010, L.P. Deble et al. 13418 (Holótipo SI, n.v.; parátipo ICN 21652!). syn nov. = Butia yatay (Mart.) Becc.

Deble et al. (2011), descreveram como espécie nova as palmeiras nativas da Região de Giruá-RS, conhecidas até então como B. yatay (Mattos 1977). Segundo a descrição original, os autores separaram esta espécie dos B. yatay nativos da região de Coatepe em Quaraí pelas seguintes características: folhas velhas que tocam o estipe (em B. yatay as folhas velhas não tocariam), estipe mais curto e largo, 3-6 × 0,5-0,6 $\mathrm{m}$ com a base dilatada (B. yatay teria 4-12 $\times 0,3-0,4 \mathrm{~m}$, com a base quase cilíndrica) e formato dos frutos amplamente 
ovais (de B. yatay seriam ovais ou turbinados).

Apesar dos endocarpos dos Butia de Giruá serem geralmente ovais e na população de Quaraí predominar a forma alongada (turbinada), este não é um caractere absoluto e considera-se os outros caracteres diferenciais muito fracos para separá-la como espécie, pois dentro de qualquer população de Butia pode-se ver indivíduos com folhas mais arqueadas, às vezes mais eretas, patentes, bem como estipe mais largo (geralmente em solos profundos e/ou férteis, como é o caso de Giruá) ou mais estreito (em solos pobres e/ou rasos). Além disso, medidas tomadas nos exemplares de Giruá mostraram valores diferentes daqueles informados na descrição da espécie nova, como o número de folhas contemporâneas: até 31 (até 40 na descrição original) e diâmetro do estipe: até $42 \mathrm{~cm}, 30-50 \mathrm{~cm}$ acima da base (entre 50-60 $\mathrm{cm}$ na descrição original).

10. Butia pulposa (Barb. Rodr.) Nehrl., Amer. Eagle 24(17): 1, 1929. Tipo: BRASIL, RIO GRANDE DO SUL, "in campis ab São Sepé, Jaguarão et Caçapava and Cult. in Jard. Bot. Rio de Jan. no 454 (Barb. Rodr., 1903, t. 68C!). = Butia odorata (Barb. Rodr.) Noblick

Barbosa Rodrigues (1891) descreveu para a região de Caçapava do Sul, São Sepé e Jaguarão uma espécie chamada Cocos pulposa sem, no entanto, definir uma localidade tipo. A descrição feita pelo autor se baseou apenas na análise dos frutos coletados por um correspondente do Jardim Botânico do RJ e a ilustração (póstuma) feita para o Sertum Palmarum Brasiliensium mostra um indivíduo aparentemente cultivado, com suas folhas parcialmente removidas, que é um costume local utilizá-las para alimentar o gado (Barbosa Rodrigues 1903). Não são encontrados palmares nativos na região citada pelo autor, apenas indivíduos dispersos pelo homem ou pela fauna ao longo de estradas e em alguns cerros.

Nehrling (1929) transferiu C. pulposa para B. pulposa (Barb. Rodr.) Nehr., já Glassman (1979), Noblick (2010) e inúmeros outros autores mantiveram este binômico como sinonímia de B. odorata. Deble et al. (2011) o revalidou como espécie, citando sua ocorrência para o litoral do Rio Grande do Sul e do Uruguai, na restinga, enquanto $B$. odorata estaria, para estes autores, restrito as áreas campestres do litoral até o departamento de Treinta y Tres no Uruguai. Segundo os protótipos, B. pulposa e $B$. odorata estariam separadas principalmente pelas características dos frutos, porém, não foram encontradas estas diferenças nos butiazais dos referidos locais. Neste caso, acredita-se que, ao escolher as plantas com os frutos maiores e mais saborosos para cultivar nos quintais, os habitantes da região centro-sul do RS vão fazendo uma seleção, rumo à domesticação da espécie (Soares \& Witeck 2009); assim, prefere-se aceitar esta entidade taxonômica como sinonímia (Glassman 1970), e mantê-la como uma variedade (Beccari 1916), na qual é muito comum nos pomares da região de Santa Maria, dentre outros municípios.

11. Butia quaraimana Deble \& Marchiori, Balduinia 33: 12. 2012. Tipo: BRASIL. RIO GRANDE DO SUL: Quaraí, Palmar de Coatepe, 15.II.2011, L.P. Deble et al.13988 (Holótipo SI, n.v.). syn. nov. = Butia yatay (Mart.) Becc.

Deble et al. (2012) descreveram os Butia da região de Coatepe (Quaraí-RS) como uma nova espécie, embora em um trabalho anterior haviam reconhecido como B. yatay (Deble et al. 2011). No último trabalho publicado, os autores comentaram ter encontrado diferenças entre os táxons de QuaraíRS e os da localidade de São Roque, na Região de Corrientes, Argentina (localidade tipo de B. yatay); na descrição original estes autores explicam:

"Devido ao tamanho das flores femininas, endocarpo alongado e frutos ovalados, providos de bico no ápice, B. quaraimana é morfologicamente similar à $B$. yatay, da qual difere por ser menos robusta, com os maiores indivíduos medindo até $8 \mathrm{~m}$ altura ( $v s$. até $16 \mathrm{~m})$, pelo estipe curto $(2,5-6,5 \mathrm{~m} v s$. 6-14 m), pelo menor número de folhas contemporâneas (12-16 vs. 16-24), pelo menor tamanho dos folíolos na parte mediana (45-65 cm × 1,2-2 cm vs. 55-80 cm $\times$ $2-3 \mathrm{~cm}$ ), e pela forma elíptica do endocarpo (vs. ovadoelíptica), que mede 18-22 × 10-12 mm (vs. 24-28 × 14-18 mm)" (Deble et al. 2012, p. 13).

No levantamento feito em 79 plantas da região de Coatepe, Soares \& Longhi (2011) encontraram dados diferentes daqueles descritos na publicação do novo binômio: embora as palmeiras que crescem sobre o neosolo litólico meçam 6-8 m alt., nos locais em que a profundidade do solo chega aos $70 \mathrm{~cm}$, foram encontradas palmeiras ca. $10 \mathrm{~m}$ alt. Número de folhas contemporâneas, 12-27; pinas medianas 67-79 $\times 2-2,4 \mathrm{~cm}$ compr. nos indivíduos adultos. Endocarpos 18-28 × 10-16 mm. Além disso, na sua ampla área de distribuição (Argentina e Uruguai), as populações de $B$. yatay apresentam muita variação na sua altura média, fato que havia sido reconhecido anteriormente por Deble et al. (2011, p. 21): 
"In Brazil, the trunk is smaller (up to $8 \mathrm{~m}$ ), compared with the typical population (Entre Rios and Corrientes provinces, Argentina); however, the size of trunk reduces in north direction (in Paso de los Libres e.g., the individuals show trunks with less than $8 \mathrm{~m}$; on the other hand, the form of leaves, size of spathes and fruits are constant in all population examined)".

Os autores Crovetto \& Piccinini (1951) também reconhecem essa variação nas alturas médias das populações de B. yatay ao longo de sua área de ocorrência. $\mathrm{O}$ porte das palmeiras parece variar muito conforme as condições ecológicas e isto pode ser observado em outras espécies como Allagoptera caudescens (Mart.) Kuntze, Attalea geraensis Barb. Rodr., Attalea funifera Mart. ex Spreng. entre outras (Lorenzi et al. 2010). Deste modo, neste trabalho, prefere-se colocar o binômio como sinonímia de B. yatay.

\section{Espécie dúbia}

12. Butia stolonifera (Barb. Rodr.) Becc. L'Agric. Col. 10(2): 492. 1916. Tipo: URUGUAI: Pan d'Azucar, pro. Montevideo (Cult. Jard. Bot. RJ n ${ }^{\circ} 2259$, n.v.).

Originalmente descrita como Cocos stolonifera Barb. Rodr. e transferida para Butia por Beccari (1916). Segundo as descrições de Barbosa Rodrigues (1903), é uma palmeira de hábito cespitoso, acaule; folhas 1,2 m compr., ereto arqueadas, 5-7 contemporânea; pecíolo 40-50 cm compr., margens com remotos espinhos; raque 80-90 cm compr.; pinas alternas, suberetas, inseridas obliquamente na raque e uniformemente arranjadas, as da parte inferior da raque $47 \times 1,7$ $\mathrm{cm}$, as da extremidade $15 \times 0,3-0,4 \mathrm{~cm}$. Flores e frutos não observados. A descrição original explica que esta é uma espécie notável pelas particularidades de seu crescimento, na qual emite rizomas subterrâneos, às vezes com mais de $2 \mathrm{~m}$ de distância da planta mãe, criando assim novos fustes. O autor escreve ainda que, pelas características do arranjo das pinas sobre a raque foliar, parece ser próxima das espécies atualmente descritas como Butia. Este fato levou Beccari (1916) a transferi-la de Cocos para Butia, mesmo sem ter observado a planta ou alguma coleta. A ocorrência natural desta espécie é frequentemente citada para o RS e para as planícies rochosas do Uruguai (Barbosa Rodrigues 1903, Beccari 1881, World Checklist Kew) e foi primeiramente encontrada pelo professor Arechavaleta em 1869, no cerro Pan de Azucar - Uruguai (Barbosa Rodrigues 1903). De lá foram retiradas duas plantas para serem cultivadas, uma em Montevidéu e outra no Jardim Botânico do Rio de Janeiro, ambas foram perdidas (Glassman 1970).

Pelo hábito rizomatoso e pelas ilustrações da obra "Sertum Palmarum Brasiliensium", a planta assemelha-se com a espécie Syagrus campylospatha (Barb. Rodr.) Becc., exceto pelo fato de possuir, segundo os desenhos, pecíolos denteados (em S. campylospatha as margens são lisas) e ponta dupla nas pinas (em $S$. campylostatha é unida e pungente, transformada em um espinho). A espécie nunca mais foi encontrada e nenhuma palmeira nativa do estado apresenta este tipo de hábito.

\section{Híbridos Naturais}

13. $\times$ Butyagrus alegretensis $\mathrm{K}$. Soares sp. hibr. nov. Tipo: BRASIL. RIO GRANDE DO SUL: Alegrete, no Cerro do Tigre (Ponte de Pedra), 29³9'48,35'S, 55'26'46,95'W, 13.VII.2012, K. Soares et al. 24 (HDCF 6264!).

Fig. $7 \mathrm{a}-\mathrm{i}$

Palma hybrida inter Butiam lallemantum et Syagrus romanzoffianam, mediana, $1-3,5 \mathrm{~m}$ alta. Stipes cum vaginis minus persistentibus quam Butia lallemantium. Rachis foliorum 111-214 cm longa, disponens 60-104 pinnae quaeque lateris, virides et splendidae; pinnarum longitudo a base ad rachis extremitatem minuit; pinnae regulariter distribuitae longe rachis et in ipso plano dispositae, aut in plus planis, sed pauca discrepantes. Bractea peduncular inflorescentiae lignosae, continens sulcos longitudinales, 104-106 totalis longitudinis, pars expansa 56-64 × 12,3-14,5 cm. Flores masculi 6-7 mm longi. Flores femini 5-6 $\mathrm{mm}$ longi. Fructus 2,5-3,0 × 1,8-2,7 cm.

Palmeira híbrida, 1,0-3,5 m alt. Estipe simples ou raramente duplo, dilatado na base, até $95 \mathrm{~cm}$ compr., 22-30 cm diâm. Folhas pinadas, 9-19 contemporâneas, arranjadas em espiral ao redor do estipe; bainha mais pseudopecíolo $33-106 \times 15 \mathrm{~cm}$, margem com dentes muito pequenos, no máximo apenas algumas fibras endurecidas; pecíolo $1-3 \times$ $1,6-3,4 \mathrm{~cm}$; raque $111-220 \times 0,8-1,4 \mathrm{~cm}$, com 60 104 pinas de cada lado; pinas da base da raque 48-76 $\times 1,4-2,6 \mathrm{~cm}$, da parte mediana 40-73 $\times 1,6-2,3 \mathrm{~cm}$, da extremidade $33-52 \times 0,9-1,4 \mathrm{~cm}$, distribuídas regularmente ao longo da raque e dispostas em um ou mais planos pouco discrepantes, sem conferir um aspecto plumoso à folha. Inflorescência andrógina, interfoliar; profilo $24,0 \times 4,0 \mathrm{~cm}$, lanceolado; bráctea peduncular lignosa, com sulcos longitudinais irregulares, $104-106 \mathrm{~cm}$ compr. total, parte expandida 56-64 × 12,3-14,5 cm; pedúnculo 


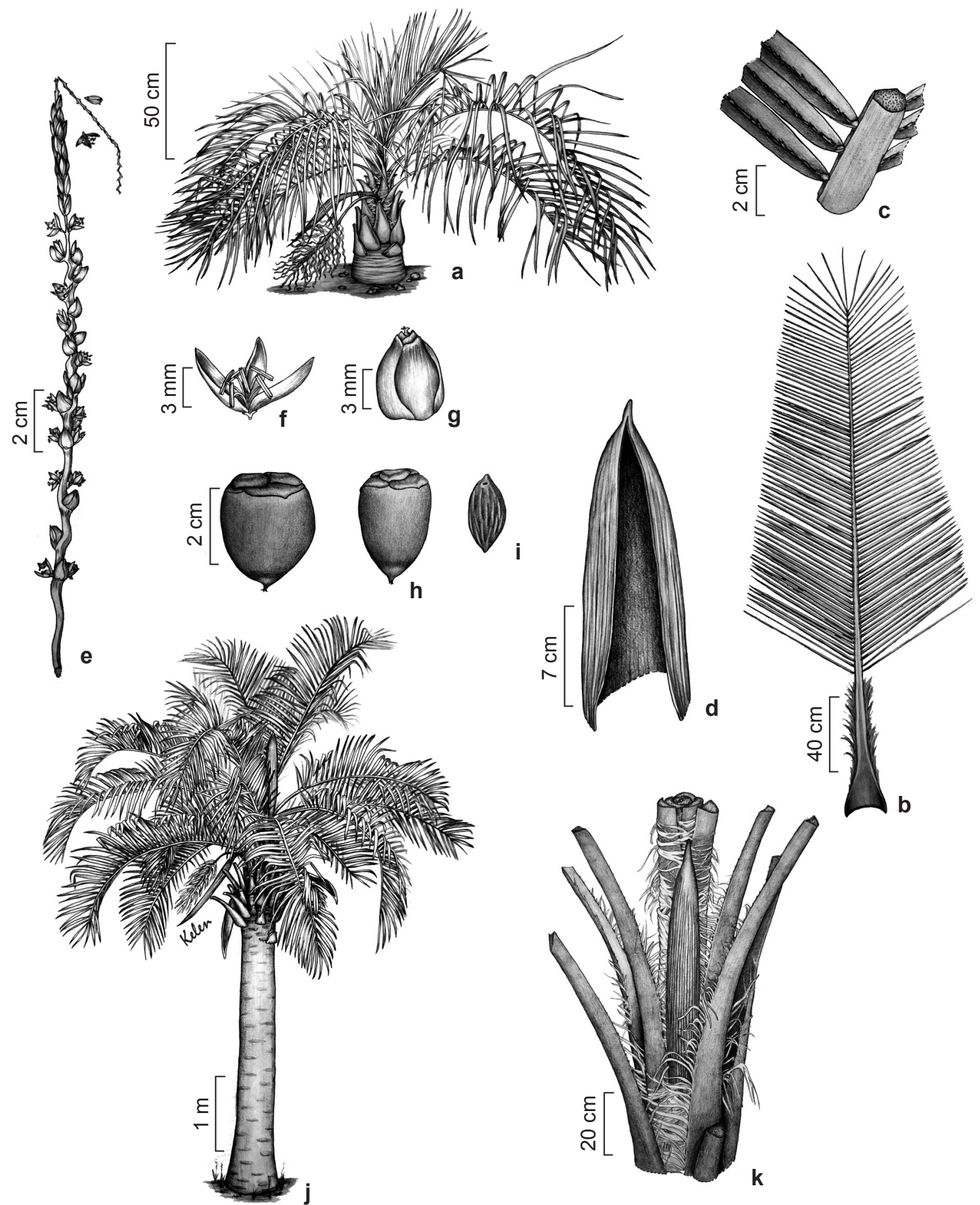

Figura 7 - a-i. $\times$ Butyagrus alegretensis K. Soares - a. hábito; b. folha; c. detalhe da folha; d. detalhe da bráctea peduncular sulcada; e. raquila; f. flor estaminada; g. flor pistilada; h. frutos; i. endocarpo (K. Soares et al. 24). j-k. $\times$ Butyagrus nabonnandii (Prosch.) Vorster $-\mathrm{j}$. hábito; k. detalhe da espata sulcada e pseudopecíolos quase inermes (K. Soares et al. 25).

Figure 7 - a-i. xButyagrus alegretensis K. Soares - a. habit; b. leaf; c. leaf detail; d. peduncular bract detail with longitudinal grooved; e. leaflet; f. staminate flower; g. pistillate flower; h. fruits; i. endocarp (K. Soares et al. 24). j-k. $\times$ Butyagrus nabonnandii (Prosch.) Vorster $-\mathrm{j}$. habit; k. peduncular bract with longitudinal grooved and pseudopetiole almost unarmed (K. Soares et al. 25). 


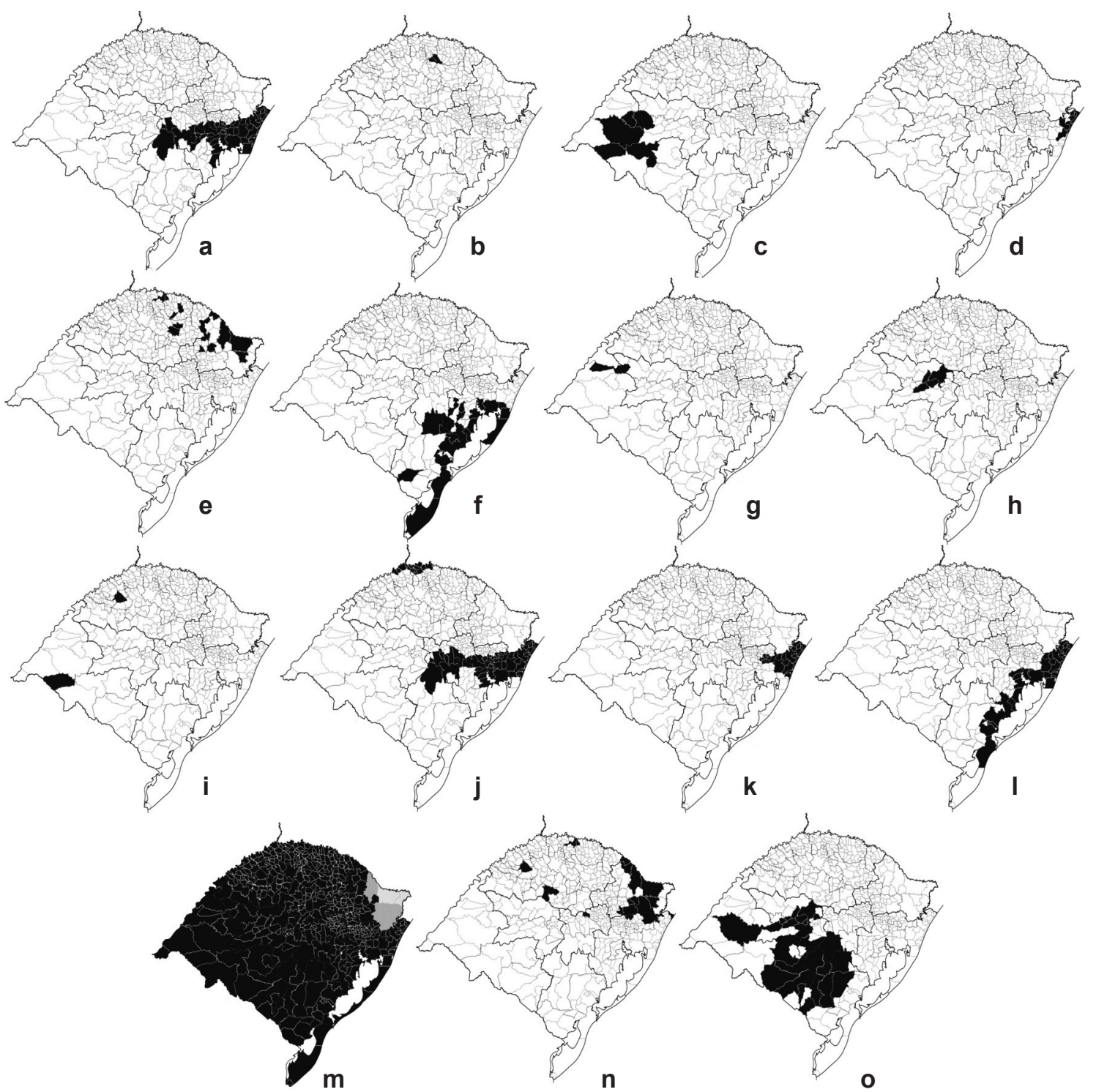

Figura 8 - a-o. Mapa de distribuição das espécies no Rio Grande do Sul - a. Bactris setosa Mart.; b. Butia exilata Deble \& Marchiori; c. Butia lallemantii Deble \& Marchiori; d. Butia catarinensis Noblick \& Lorenzi; e. Butia eriospatha (Mart. Ex Drude) Becc.; f. Butia odorata (Barb. Rodr.) Noblick; g. Butia paraguayensis (Barb. Rodr.) L. H. Bailey; h. Butia witeckii K. Soares \& S. Longhi; i. Butia yatay (Mart.) Becc.; j. Euterpe edulis Mart.; k. Geonoma gamiova Barb. Rodr.; 1. Geonoma schottiana Mart.; m. Syagrus romanzoffiana (Cham.) Glassman.; n. Trithrinax acanthocoma Drude; o. Trithrinax brasiliensis Mart.

Figure 8 - a-o. Distribution map of the species in Rio Grande do Sul state. - a. Bactris setosa Mart.; b. Butia exilata Deble \& Marchiori; c. Butia lallemantii Deble \& Marchiori; d. Butia catarinensis Noblick \& Lorenzi; e. Butia eriospatha (Mart. Ex Drude) Becc.; f. Butia odorata (Barb. Rodr.) Noblick; g. Butia paraguayensis (Barb. Rodr.) L. H. Bailey; h. Butia witeckii K. Soares \& S. Longhi; i. Butia yatay (Mart.) Becc.; j. Euterpe edulis Mart.; k. Geonoma gamiova Barb. Rodr.; 1. Geonoma schottiana Mart.; m. Syagrus romanzoffiana (Cham.) Glassman.; n. Trithrinax acanthocoma Drude; o. Trithrinax brasiliensis Mart. 
41-52 × 1,1-2,5 cm; raque da inflorescência 33-49 cm compr., com 93-103 ráquilas; ráquilas 10-35 $\mathrm{cm}$ compr. Flores amarelas; estaminadas 6-7 mm compr.; pistiladas 7-8 mm compr. Frutos amarelos, alaranjados ou amarelo-esverdeados, 2,5-3,0 $\times$ $1,8-2,7 \mathrm{~cm}$; endocarpo ósseo, 1,8-2,6 × 0,9-1,4 $\mathrm{cm}$, superfície quase lisa, cavidade interna regular contendo 1-2 sementes.

Material selecionado: BRASIL. RIO GRANDE DO SUL: Alegrete, no Cerro do Tigre (Ponte de Pedra), $29^{\circ} 39^{\prime} 48,35^{\prime}$ ' S, 5526'46,95” W, 13.VII.2012, fl. e fr., K. Soares et al. 24 (HDCF 6264!).

Trata-se de um híbrido natural entre as espécies B. lallemantii e S. romanzoffiana, encontrado em 2007 no Cerro do Tigre em Alegrete. Neste local existem quatro híbridos adultos e três jovens, sendo um deles com estipe duplo. Outra planta foi localizada em São

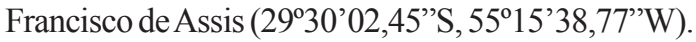
Semelhante ao $\times$ Butyagrus nabonnandii, no entanto, de hábito consideravelmente menor.

Etimologia: o nome latinizado menciona o município de Alegrete-RS, local onde foram encontrados um grande número de híbridos naturais.

14. $\times$ Butyagrus nabonnandii (Prosch.) Vorster, Taxon 39: 662. 1990. Tipo: $\times$ Butiarecastrum nabonnandii Prosch. (Lectótipo: Revue Horticole 93, fig 72, p. 291. 1921, n.v.). Fig. 7j-k

Estipe 4-10 $\times 0,4-0,5 \mathrm{~m}$, liso. Folhas pinadas, 12-25 contemporâneas; bainha semi persistente, ca. $140 \mathrm{~cm}$ compr.; pseudopecíolo com dentes pouco pronunciados na sua margem, geralmente apenas fibras engrossadas; raque pouco curvada, 2,3-3,3 m compr., com 100-130 pares de pinas; pinas da parte mediana da raque $80-110 \times 2,5-3,0 \mathrm{~cm}$, verdes e brilhantes. Inflorescências interfoliares; pedúnculo até $80 \mathrm{~cm}$ compr:; bráctea peduncular sulcada, parte expandida 100-160 × 14-17 cm; eixo da inflorescência 95-150 cm compr., com 90-130 ráquilasde 30-80 cm compr. Flores amarelas; pistiladas $5-7 \mathrm{~cm}$ compr.; estaminadas 5-6 mm compr. Frutos ovóides ou globosos, 1,5-2,5 $\times 2,0-2,6 \mathrm{~cm}$; endocarpo ósseo, com cavidade interna irregular, contendo 1-2 sementes.

Material selecionado: BRASIL. RIO GRANDE DO SUL: São Vicente do Sul, 2941'14.38"S 5440'38.80"O (cultivado), 13.VII.2012, K. Soares et al. 25 (HDCF 6265).

Batizado por Proschowsky (1921) em homenagem a um horticultor francês que havia cruzado artificialmente as espécies $B$. odorata e $S$. romanzoffiana, no entanto, este híbrido ocorre naturalmente nas áreas onde as duas espécies crescem juntas. Comum em jardins domésticos e pomares, onde seus progenitores são frequentemente cultivados. É bastante cultivada em alguns países europeus e nos Estados Unidos devido a sua adaptação ao frio, crescimento rápido e beleza (Riffle et al. 2012). Suas sementes são consideradas estéreis, por isto é chamada de palmeira-mula, no entanto seu pólen pode ser utilizado para produção de retro-cruzamentos, inclusive com o gênero Jubaea (Riffle et al. 2012).

\section{Agradecimentos}

Agradecemos às pessoas que ajudaram durante as coletas de material botânico: Camila Andrzejewski, Cristina G. Redin, Henrique Büneker, Rafael M. Callegaro e Rodrigo C. Pontes. Também às instituições que colaboraram na realização deste trabalho: Colégio Politécnico da UFSM, Instituto Plantarum de Estudos da Flora e ao Programa de Pós Graduação da Engenharia Florestal da UFSM. À professora Leila Teresinha Maraschin a diagnose em latim de $\times$ Butyagrus alegretensis. À professora Thais Scotti do CantoDorow as valiosas sugestões. Aos curadores dos herbários visitados.

\section{Referências}

Báez, J.R. 1933. Noticia sobre la distribución de las palmeras en la flora de Entre Ríos. Memorias del Museo de Paraná, Botánica 5: 1-11.

Barbosa Rodrigues, J. 1891. Plantas novas cultivadas no Jardim Botânico do Rio de Janeiro I. Rio de Janeiro, Typographia Leuzinger. Pp. 5-33

Barbosa Rodrigues, J. 1899. Palmae novae Paraguayenses. Typographia Leuzinger, Rio de Janeiro. 66p.

Barbosa Rodrigues, J. 1903. Sertum Palmarum Brasiliensium. Imprimerie Typographique Veuve Monnom, Bruxeles. 2 vol., 1: 1-140; 2: 1-114.

Barbosa Rodrigues, J. 1907. Supplementum ad Sertum Palmarum Brasiliensium. Contributions du Jardin Botanique de Rio de Janeiro 6: 13.

Beccari, O. 1916. Il genere Cocos Linn. E Le palme affini. l'Agricoltura Coloniale 10: 489-524.

Bondar, G. 1964. Palmeiras do Brasil. Instituto de Botânica de São Paulo, São Paulo. 159p.

Brussa Santander, C.A. \& Grela Gonzáles, I.A. 2007. Flora arbórea Del Uruguay, com énfasis em lãs especies de Rivera y Tacuarembó. Cofusa, Montevideo. 544p.

Carvalho, P.H.R. 2006. Espécies arbóreas brasileiras. Vol. 2. Embrapa Informações Tecnológicas, Brasília. 627p.

Carvalho, P.H.R. 2010. Espécies arbóreas brasileiras. Vol. 4. Embrapa Informações Tecnológicas, Brasília. $644 \mathrm{p}$. 
Chebataroff, J. 1971. Palmeras del Uruguay. Facultad de Humanidades y Ciencias, Montevideo. 31p.

Consema. 2003. Decreto estadual $n^{\circ}$ 42.099: Lista final das espécies da flora ameaçadas de extinção no Rio Grande do Sul. Disponível em <http://www. fzb.rs.gov.br/downloads/flora ameacada.pdf $>$. Acessado em 11 de Ago de 2012.

Crovetto, R.M. \& Piccinini, B.G. 1951. La vegetación de La Republica Argentina. 1. Los palmares de Butia yatay. Revista de Investigacion Agrícola 4: 153-242.

Deble, L.P.; Marchiori, J.N.C.; Alves, F.D. \& OliveiraDeble, A.S. 2011. Survey on Butia (Becc.) Becc. (Arecaceae) from Rio Grande do Sul state (Brazil). Balduinia 30: 3-24.

Deble, L.P.; Marchiori, J.N.C.; Alves, F.D. \& OliveiraDeble, A.S. 2012. Butia quaraimana (Arecaceae), uma nova espécie para o Rio Grande do Sul (Brasil). Balduinia 33: 9-24.

Dransfield, J.; Uhl, N.W.; Asmussen, C.B.; Baker, W.J.; Harley, M.M. \& Lewis, C.E. 2008. Genera Palmarum: the evolution and classification of palms. Kew Publishing, Royal Botanical Garden, Londres. $732 \mathrm{p}$.

Drude, O. 1878. C. Ueber die Gattung Trithrinax und eine neue kultivirte Art derselben. Gartenflora, 27: 359-363.

Drude, O. 1882. Palmae. In: Martius, C.F.P.; Eichler, A.W. \& Urban, I. (eds.). Flora brasiliensis. München, Wien, Leipzig. Vol. 3, part. 2. 551p.

Glassman, S.F. 1970. Conspectus of the palm genus Butia Becc. Fieldiana: Botany 32: 127-172.

Glassman, S.F. 1979. Re-evaluation of the genus Butia with a description of the new species. Principes 23: 65-79.

Henderson, A. 2011. A revision of geonoma (Arecaceae). Phytotaxa 17: 1-271.

Henderson, A.; Galeano, G. \& Bernal, R. 1995. Field guide to the palms of the Americas. Pinceton University Press, New Jersey. 363p.

Huek, k. 1972. As florestas da América do Sul: ecologia, composição e importância econômica. Editora da Universidade de Brasília, Brasília. 466p.

IUCN. 2012. Red List of Threatened Species. Version 2012.1. Disponível em <www.iucnredlist.org>. Acessado em 15 Ago 2012.

Jacquin, N.J. 1763. Selectarum Stirpium Americanarum Historia. In: Qua as Linnaeanum Systema Determinae Descriptaeque Sistuntur Plantae Illae. Viena. Pp. 278-279.

Johnson, D.V. 1998. Non-wood forest products 10: tropical palms. [S.1.]. Food and Agriculture Organization of the United Nations (FAO). Disponível em <http://www.fao.org/docrep/x0451e/ x0451e00.HTM>. Acesso em 12 Jan 2010.

Klein, R.M. 1975. Southern Brazilian phytogeographic features and the probable influence of Upper Quartenary climate changes in the floristic distribuition. Boletim Paranaense de Geociências 33: $67-88$.

Krapovickas, A. \& Dematteis, M. 2008. Butia eriospatha (Drude) Becc., palmera naturalizada em el norte de Misiones (Argentina). Bonplandia 17: 91-92.

Leitman, P.; Henderson, A.; Noblick, L. \& Martins, R.C. 2012. Arecaceae. In: Lista de espécies da flora do Brasil. Jardim Botânico do Rio de Janeiro. Disponível em <http://floradobrasil.jbrj.gov. br/2012>. Acesso em 27 Jan 2013.

Lindman, C.A.M. 1906. A vegetação do Rio Grande do Sul. Tipografia da Livraria Universal de Echenique Irmãos \& Cia, Porto Alegre. 356p.

Lombardo, A. 1964. Flora arbórea y arborescente del Uruguay. 2 ed. Concejo Municipal, Montevideo. 218p.

Lorenzi, H. 2010. Geonoma. In: Lorenzi, H.; Noblick, L.R.; Kahn, F. \& Ferreira, E. Flora brasileira: Arecaceae (Palmeiras). Instituto Plantarum, Nova Odessa. Pp. 214-255.

Lorenzi, H.; Moreira de Souza, H.; Medeiros-Costa, J.D.; Coelho de Serqueira, L.S. \& Ferreira, E. 2004. Palmeiras brasileiras e exóticas cultivadas. Instituto Plantarum, Nova Odessa. 432p.

Lorenzi, H.; Noblick, L.R.; Kahn, F. \& Ferreira, E. 2010. Flora brasileira: Arecaceae (Palmeiras). Instituto Plantarum, Nova Odessa. 382p.

McNeill, J.; Barrie, F.R.; Buck, W.R.; Demoulin, V.; Gruter, W.; Hawksoworth, D.L.; Herendeen, P.S.; Knapp, S.; Marhold, K.; Prado, J.; Prud'Homme Van Reine, W.F.; Sith, G.F.; Wiersema, J.H. \& Turland, N.J. 2012. International Association for Plant Taxonomy: Article 8. Disponível em $<$ http://www.iapt-taxon.org/nomen/ main.php>. Acesso em 30 Mar 2013.

Marchiori, J.N.C. \& Alves, F.S. 2011. O palmar de Coatepe (Quaraí, RS): enfoque fitogeográfico. Balduinia 28: 21-26

Martius, C.F.P. 1844. Palmetum Orbignyanum. Voyage dans l'Amérique Meridionale 7. Paris. Pp. 44-45.

Mattos, J.R. 1977. Palmeiras do Rio Grande do Sul. Roessleria 1: 5-94.

Nehrling, H. 1929. Butia palms. American Eagle Estero, v. 24, n. 17, 1p.

Noblick, L.R. 2010. Butia (Becc.) Becc. In: Lorenzi, H.; Noblick, L.R.; Kahn, F. \& Ferreira, E. Flora brasileira: Arecaceae (Palmeiras). Instituto Plantarum, Nova Odessa. Pp. 159-183.

Noblick, L.R. \& Lorenzi, H. 2010. New Syagrus species from Brazil. Palms 54: 18-42.

Pingitore, E.J. 1978. Revision de las species del genero Trithrinax (Principales). Revista Del Instituto Municipal de Botânica 4: 95-109

Proschowsky, A.R. 1921. Un beau palmier hybride. Butiarecastrum Nabonnandi. Revue Horticole 93: 290-291.

Rambo, S.J. 1956. A fisionomia do Rio Grande do Sul. $3^{\text {a }}$ ed. Editora Unisinos, São Leopoldo. 473p. 
Reitz, R. 1974. Palmeiras. In: Flora ilustrada catarinense. Herbário Barbosa Rodrigues, Itajaí. 189p.

Riffle, R.L; Craft, P. \& Zona, S. 2012. The encyclopedia of cultivated palms. Timber Press, Portland. 516p.

Rossato, M. 2007. Recursos genéticos de palmeiras do gênero Butia do Rio Grande do Sul. Tese de Doutorado. Universidade Federal de Pelotas, Pelotas. 136f.

Saraiva, D.D.; Salengue, E.V.; Souza, C.A. \& Souza, K.S. 2005. Conservação de comunidades vegetais de restinga no município de Pelotas e entorno Rio Grande do Sul, Brasil. Disponível em <www.ufpel. edu.br/cic/2005/arquivos/CB_00671.rtf>. Acesso em 12 Jun 2012.

Soares, K.P. 2013. O gênero Butia (Becc.) Becc. (Arecaceae) no Rio Grande do Sul com ênfase nos aspectos ecológicos e silviculturais de Butia yatay (Mart.) Becc. e Butia witeckii K. Soares \& S. Longhi. Dissertação de Mestrado. Universidade Federal de Santa Maria, Santa Maria. 135f.

Soares, K. \& Witeck Neto, L. 2009. Ocorrência de Butia capitata e outras espécies do gênero Butia na região central do Rio Grande do Sul, Brasil. In: Geymonat, G. \& Rocha, N. M'botiá: ecossistema único em el mundo. Casa Ambiental, Castilhos, Rocha. Pp. 37-41.

Soares, K.P. \& Longhi, S.J. 2011. Uma nova espécie de Butia (Becc.) Becc. (Arecaceae) para o Rio Grande do Sul, Brasil. Ciência Florestal 21: 203-208.

Sobral, M.; Jarenkow, J.A.; Brack, P.; Irgang, B.; Larocca, J. \& Rodrigues, R.S. 2006. Flora arbórea e arborescente do Rio Grande do Sul, Brasil. Novo Ambiente, São Carlos. 350p.

Sühs, R.B. \& Putzke, J. 2010. Nota sobre a ocorrência de uma população de Trithrinax brasiliensis Martius (arecaceae) no Vale do Rio Pardo, Rio Grande do Sul, Brasil. Pesquisas Botânica 61: 330-332.

Thiers, B. 2012. Index Herbariorum: a global directory of public herbaria and associated staff. New York Botanical Garden's Virtual Herbarium. Disponível em $<$ http://sweetgum.nybg.org/ih/>. Acesso em 25 Ago 2012.

Tomlinson, P.B. 1961. Anatomy of the monocotyledons II: palmae. Oxford University Press, Oxford. 453p.

Zambrana, N.Y.P.; Byg, A.; Svenning, C.C.; Moraes, M.; Grandez, C. \& Balsley, H. 2007. Diversity of palm uses in the western Amazon. Biodiversity and Conservation 16: 2771-2787.

\section{Lista de Exsicatas}

Abreuzzi, M.L.: 5215 (4.2 HAS). Alvarez, A.: 11 (6.2 ICN), 13 (2.1 ICN), 16 (2.5 ICN). Arbo, M.M.: 553 (2.8 CTES). Baptista, L.: HAS 786 (4.2), ICN 29453 (4.2), ICN 31050 (4.2). Benetti, A.: HAS 4599 (6.1). Cossio: 61 (6.2 ICN), 67 (6.1 ICN). Deble, L.P.: 12854 (2.4 CTES), 13422 (2.1 CTES). Franco, E.: ICN 6430 (2.8). Freitas, E.: 98 (2.2 ICN). Glaziou, A.F.M.:8059 (2.4 K), 9014 (6.1 C). Hassler: 8554 (2.6 G). Irgang, B.: 293 (2.5 ICN), ICN 4760 (1.1), ICN 21652 (2.8), ICN 26908 (2.1), ICN 27999 (1.1), ICN 29501 (2.3), ICN 32392 (2.2). Jarenkow, J.A.: 530 (4.2 PEL), 804 (1.1 PEL), 1270 (4.2 PEL), 1842 (4.2 PEL), 2290 (3.1 PEL), 2546 (4.1 PEL). Jurinitz, C.: 18 (4.1 ICN), 20 (1.1 ICN), 26 (4.2 ICN). Kinupp, V.F.: 2867 (2.5 ICN), 2961 (2.8 ICN). Lima, L.: 319 (4.2 ICN). Lima, L.F.: 318 (1.1 ICN). Lindeman, F.: ICN 9490 (6.1). Lorenzi, H.: 6760 (2.3 HPL), 6838 (2.5 HPL), 6839 (2.3 HPL). Luederwaldt: SP 12267 (8). Mattos, J.: 1963 (2.5 HAS), 11455 (2.5 HAS), 15616 (6.1 SP), 17212 (2.1 HAS), 17302 (2.1 HAS), 21875 (4.1 HAS). Porto, M.L.: HAS 1167 (2.5). Rambo, B.: PACA 241 (4.1), PACA 242 (2.5), PACA 2090 (4.2), PACA 2019 (3.1), PACA 26090 (2.2), PACA 34032 (4.2), PACA 38016 (2.2), PACA 42217 (4.2), PACA 45278 (2.2), PACA 45905 (3.1), PACA 46001 (2.3), PACA 47141 (4.1), PACA 52018 (2.4), PACA 63567 (6.2). Reis, A.: 2611 (6.2 HBR), 2613 (6.2 HBR). RGS: 311 (6.1 HAS). Rossato: 17 (6.1 NY). Salazar: ICN 116565 (6.2). Schultz, A.R.: ICN 20757 (1.1). Sellow, F.: M 18498 (6.2). Senna, R.M.: 942 (4.2 HAS), HAS 47695 (2.5). Setubal R.: 399 (4.2 ICN). Sevegnani, L.: ICN 103851 (1.1). Silveira, N.: 10842 (4.2 HAS). Soares, K.P.: 1 (2.6 HDCF), 4 (2.6 HDCF), 8 (8 HDCF), 17 (2.6 HDCF), 23 (6.2 HDCF), 24 (13 HDCF), 25 (14 HDCF), 26 (2.8 HDCF), 27 (7.2 HDCF), 28 (7.1 HDCF), 29 (1.1 HDCF), 30 (2.4 HDCF), 31 (6.1 HDCF), 32 (2.5 HDCF), 33 (3.1 HDCF), 34 (4.1 HDCF), 35 (5.1 HDCF), 36 (4.2 HDCF), 37 (2.2 HDCF), 38 (2.5 HDCF), 39 (2.5 HDCF), 42 (2.1 HDCF), 43 (2.5 HDCF), 45 (6.2 HDCF), ICN 173744 (2.7), HDCF 6213 (2.7), HDCF 6214 (2.8). Valls, J.: ICN 9937 (4.1). Viana, E.: ICN 21019 (2.2). Waechter, J.L.: 2028 (1.1 ICN), 2102 (6.1 ICN), 2137 (1.1 ICN), 2144 (2.3 ICN), 2289 (4.1 ICN), 2315 (4.2 HAS). Wasum, R.: PACA 109178 (6.1), PACA 109179 (6.2). Záchia, R.: 725 (1.1 ICN), 727 (2.3 ICN), 726 (4.1 ICN), 729 (4.2 ICN), 5873 (2.2 SMDB). 